\title{
Notes on Afrotropical Pyrgodesmidae, 1 (Diplopoda: Polydesmida)
}

\section{Заметки по афротрипическим Pyrgodesmidae, 1 (Diplopoda: Polydesmida)}

\author{
S.I. Golovatch ${ }^{1}$, D. VandenSpiegel ${ }^{2}$ \\ С.И. Головач ${ }^{1}$, А. ВанденШпигель ${ }^{2}$
}

\author{
${ }^{1}$ Institute for Problems of Ecology and Evolution, Russian Academy of Sciences, Leninsky prospekt 33, Moscow 119071 Russia. \\ ${ }^{1}$ Институт проблем экологии и эволюции РАН, Ленинский пр-т, 33, Москва 119071 Россия. \\ ${ }^{2}$ Musée Royal de l'Afrique Centrale, B-3480 Tervuren, Belgique. \\ ${ }^{2}$ Королевский музей Центральной Африки, Тервюрен, Бельгия.
}

KEY WORDS: millipede, Pyrgodesmidae, taxonomy, new records, new species, Africa.

КЛЮЧЕВЫЕ СЛОВА: диплопода, Pyrgodesmidae, таксономия, новые находки, новые виды, Африка.

ABSTRACT. New faunistic records and abundant illustrations are provided for Procoptodesmus diffusus Brolemann, 1920, Nonnodesmus niger Attems, 1953 and Stylodesmus horridus Cook, 1895. The genera Cachania Schubart, 1955 and Udodesmus Cook, 1896 (= Hercodesmus Cook, 1896, = Euhercodesmus Schubart, 1955, both syn.n.) are reviewed and rediagnosed, with keys given to all of their four and nine species, respectively, including $C$. spiniger sp.n., C. taenia sp.n., C. furcata sp.n., U. harpago sp.n. and U. liber sp.n.

РЕЗЮМЕ. Приведены новые фаунистические находки и обильные иллюстрации Procoptodesmus diffusus Brolemann, 1920, Nonnodesmus niger Attems, 1953 и Stylodesmus horridus Cook, 1895. Даны обзоры и новые диагнозы родов Cachania Schubart, 1955 и Udodesmus Cook, 1896 (= Hercodesmus Cook, 1896, =Euhercodesmus Schubart, 1955, оба syn.n.), а также ключи соответственно для всех их четырех и девяти видов, включая C. spiniger sp.n., C. taenia sp.n., C. furcata sp.n., U. harpago sp.n. и U. liber sp.n.

\section{Introduction}

The mainly tropical millipede family Pyrgodesmidae is among the largest, but taxonomically perhaps most confused in the entire class Diplopoda, currently counting almost 400 species or subspecies in 170+ genera, nearly 120 of which are monotypic [Jorgensen \& Sierwald, 1910; updated].

The present paper puts on record several species of Pyrgodesmidae, including five new, from various parts of tropical Africa.

\section{Material and methods}

All material derives from the collection of the Musée Royal de l'Afrique Centrale (MRAC), Ter- vuren, Belgium, with only a few duplicates donated to the Zoological Museum, State University of Moscow (ZMUM), Russia. The samples are stored in 70\% ethanol. Specimens for scanning electron microscopy (SEM) were air-dried, mounted on aluminium stubs, coated with gold and studied using a JEOL JSM6480LV scanning electron microscope. Photographs were made with a Leica digital camera Leica DFC 500 mounted on a Leica MZ16A stereomicroscope. Images were processed with the Leica Application Suite software.

Faunistic records and descriptions

Procoptodesmus diffusus Brolemann, 1920

Figs 1, 2.

MATERIAL. 6 ex. (MRAC 18038), Kenya, Taita Hills, Mbololo Forest, S $03^{\circ} 19^{\prime}$, E $038^{\circ} 27^{\prime}$, 1800-1900 m a.s.l, sieved litter, 2-10. VII.1999, leg. R. Mwakos; 2 F (MRAC 18086), same locality, pitfall traps, III-IV.1999, leg. L. Rogo; 5 ex. (MRAC 18125), same locality, Winkler extraction, 22.VI.1999, leg. D. VandenSpiegel; 15 ex. (MRAC 18566), same data, Winkler extraction, 8.XII.1999; 12 ex. (MRAC 18471), $1 \sigma^{7}, 1$ (ZMUM 22345$)$, Taita Hills, Yale Forest, S 03³9', E 038 33', litter, 6.XII.1999; 28 ex. (MRAC 18550), same data, Winkler extraction; 4 ex. (MRAC 18499), Taita Hills, Fururu Forest, S $03^{\circ} 26^{\prime}$, E $038^{\circ} 20^{\prime}$, Winkler extraction, 9.XII.1999; 23 ex. (MRAC 18548), same data; 1 ex. (MRAC 18513), Taita Hills, Ngangao Forest, S $03^{\circ} 22^{\prime}$, E $038^{\circ} 21^{\prime}$, 4.XII. 1999; 6 ex. (MRAC 18562), same data, Winkler extraction; $3 \bigcirc^{\top} \sigma^{\top}$, 4 우 (MRAC 18563), Taita Hills, Saga Forest, S 0350', E 038 58', 5.XII.1999; ca 100 ex. (MRAC 18579), Taita Hills, Mwachora Forest, S $03^{\circ} 24^{\prime}$, E $038^{\circ} 22^{\prime}$, Winkler extraction, 10.XII. 1999, all leg. D. VandenSpiegel \& J.P. Michiels.

REMARKS. This species which represents a monotypic genus, Procoptodesmus Brolemann, 1920, has hitherto been known only from a high-altitude forest patch (2700-2800 m a.s.1.) on Mount Kilimandjaro, Tanzania [Brolemann, 1920]. The above, remote records in the Taita Hills, Kenya show that $P$. diffusus is probably a montane species quite widely distributed in eastern Africa. 

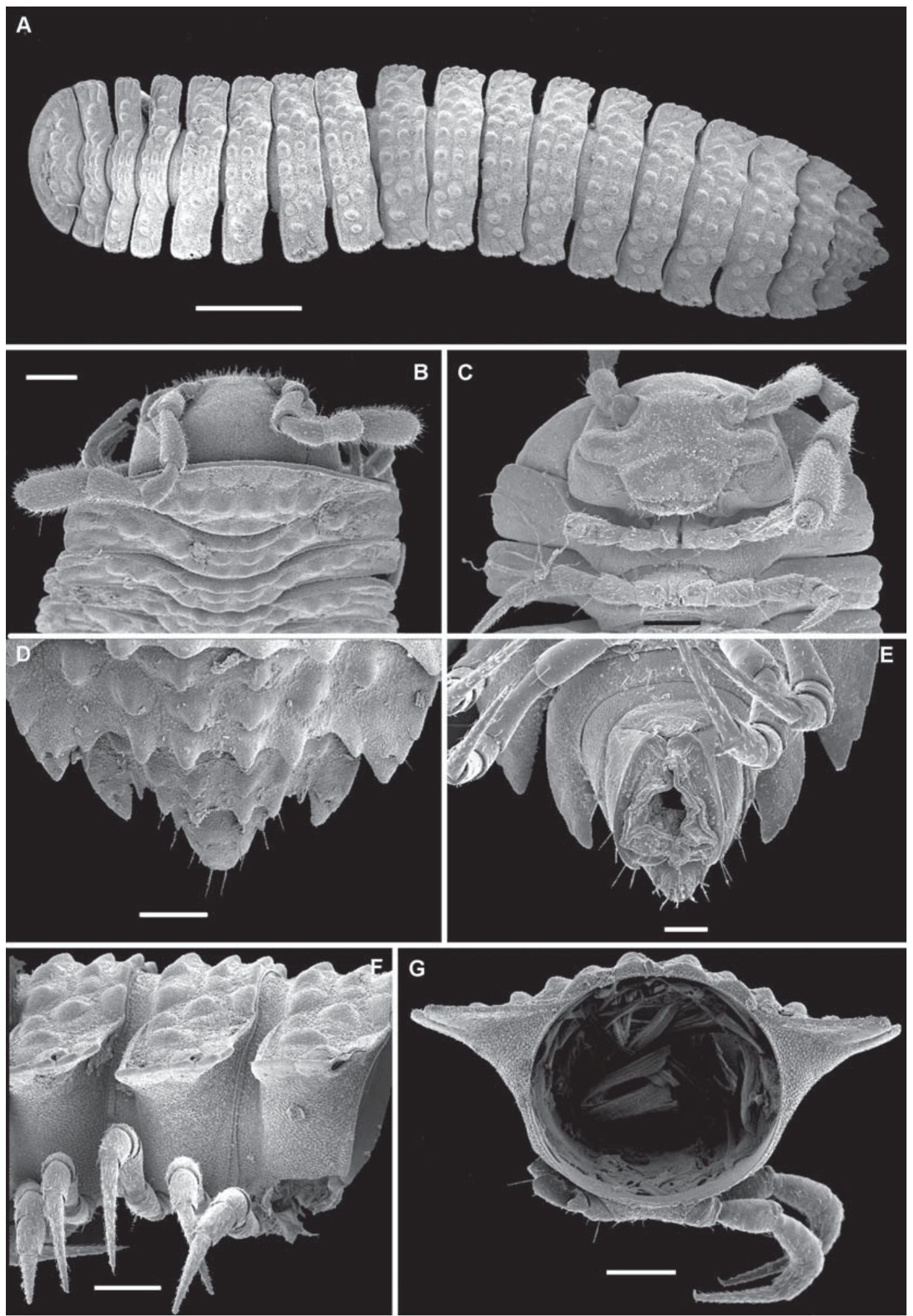

Fig. 1. SEM micrographs of Procoptodesmus diffusus Brolemann, 1920, o7 from Mwachora Forest: A - habitus, dorsal view; B \& C anterior part of body, anterodorsal and ventral views, respectively; D \& E - posterior part of body, dorsal and ventral views, respectively; F - midbody segments, lateral view; G - cross-section of a midbody segment, caudal view. Scale bars: 1.0 (A), 0.2 (B-D, F, G) \& 0.1 $\mathrm{mm}(\mathrm{E})$.

Рис. 1. СЭМ-микрогафии Procoptodesmus diffusus Brolemann, 1920, О7 из леса Mwachora: А — общий вид, сверху; В, С передняя часть тела, соответственно одновременно спереди и сверху, а также снизу; D, E - задняя часть тела, соответственно сверху и снизу; F - среднетуловищные сегменты, сбоку; $\mathrm{G}$ - поперечный срез через среднетуловищный сегмент, сзади. Масштаб: 1,0 (A), 0,2 (B-D, F, G) и 0,1 мм (Е). 

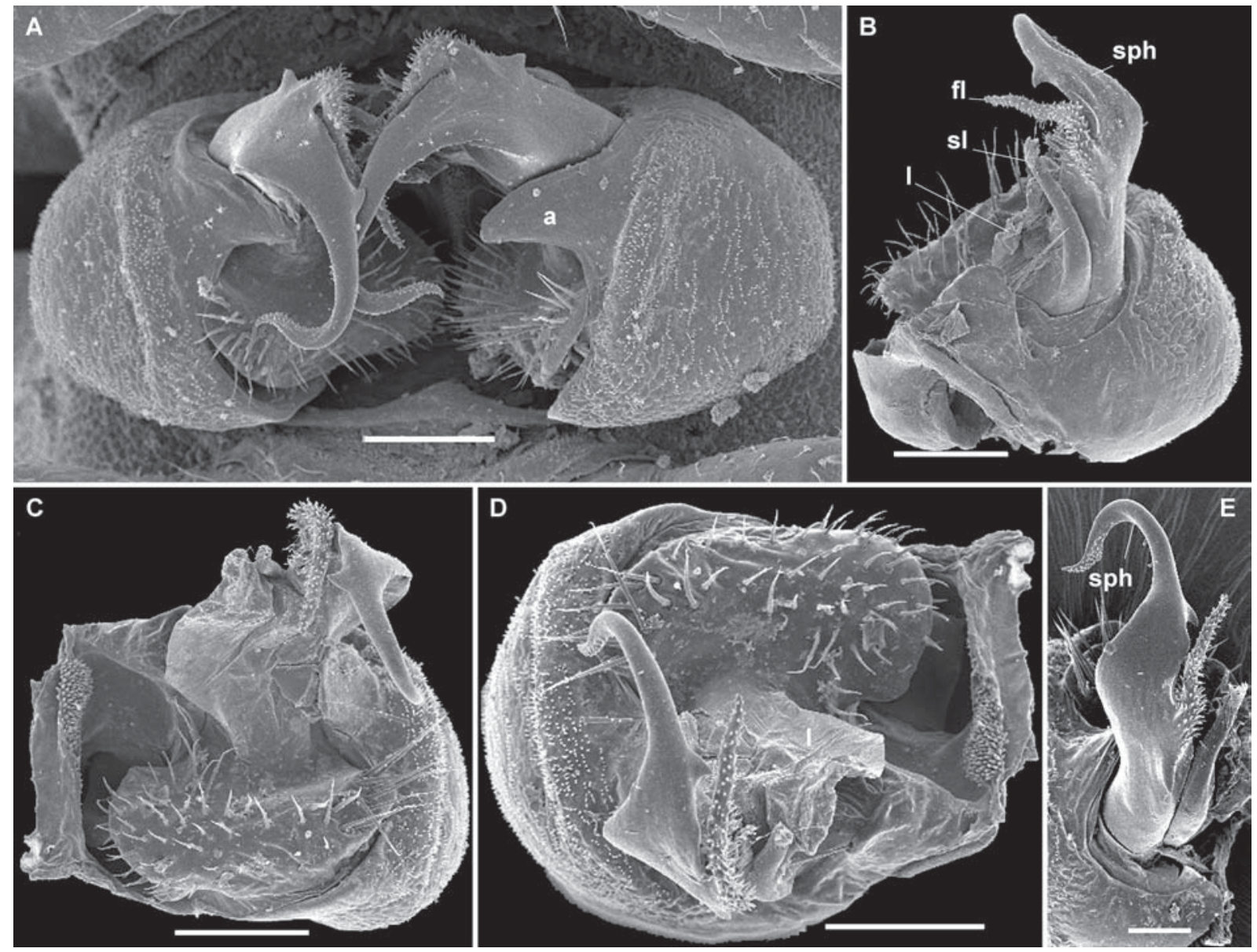

Fig. 2. SEM micrographs of gonopod structure of Procoptodesmus diffusus Brolemann, 1920, $0^{\top 7}$ from Mwachora Forest: A - both gonopods in situ, ventral view; B-E - left gonopod, mesal, anterior, ventral and posteroventral views, respectively. Scale bars $0.1 \mathrm{~mm}$. Designations in text.

Рис. 2. СЭМ-микрографии стуктуры гонопода Procoptodesmus diffusus Brolemann, 1920, о из леса Mwachora: А - оба гонопода in situ, снизу; В-E - левый гонопод, соответственно изнутри, спереди, снизу и одновременно сзади и снизу. Масштаб 0,1 мм. Обозначения в тексте.

The material from Kenya agrees perfectly well with the excellent original description. The new samples are illustrated to document their identity (Figs $1 \& 2$ ). The species is easily recognizable both through somatic characters (e.g. a cryptodesmoid body with high paraterga and non-differentiated metatergal tubercles, a smooth head, long antennae and legs) and gonopod structure (coxae subglobose, each bearing a prominent apicolateral, subtriangular aphophysis (a); telopodites well exposed, consisting of a long, sigmoid, acuminate solenophore (sph), a shorter, densely fringed, flagelloid branch (fl), a mesal, parabasal, membranous lobe (l) and a short solenomere (sl) nearby).

\section{Nonnodesmus niger Attems, 1953}

Figs 3, 4 .

MATERIAL. $5 O^{\top} \sigma^{\top}, 3$ 오, 8 juv. topotypes (MRAC 8800), Congo Belge, Kivu, Nyakasiba, 1951, leg. N. Leleup, det. C. Attems, 1951; 7 O $^{7}, 25$ 우, 27 juv. (MRAC 2136), $1 \bigcirc^{\prime}, 1$ 오 (ZMUM p2436), Democratic Republic of the Congo, Parque Nacional Albert, secteur Ruwenzori, Berlese extraction, 1956?, leg. R.P. Celis.
REMARKS. This species which represents a monotypic genus, Nonnodesmus Attems, 1953, has hitherto been known only from two montane localities in the Kivu National Park (up to 2350 m a.s.1.), Democratic Republic of the Congo [Attems, 1953].

The new material, which partly represents topotypes identified by Attems himself, agrees well with the quite poor original description. Some specimens have since faded to light brown. The new samples are properly illustrated to document their identity (Figs 3 $\& 4)$, the peculiar denticles on top of a broad apical velum (ve), a distinct, simple, digitiform solenomere (sl), an even longer, shaggy, flagelloid branch (fl) located near two higher processes $(\mathbf{x} \& \mathbf{z})$ of the gonopod being especially characteristic.

\section{Stylodesmus horridus Cook, 1895}

Fig. 5.

MATERIAL. $1 \sigma^{7}, 1$ ' "paratypes" (= syntypes) (MRAC 1117611177), Liberia, Mt. Coffee, 1896, leg. G.N. Collins, gift of Dr. 

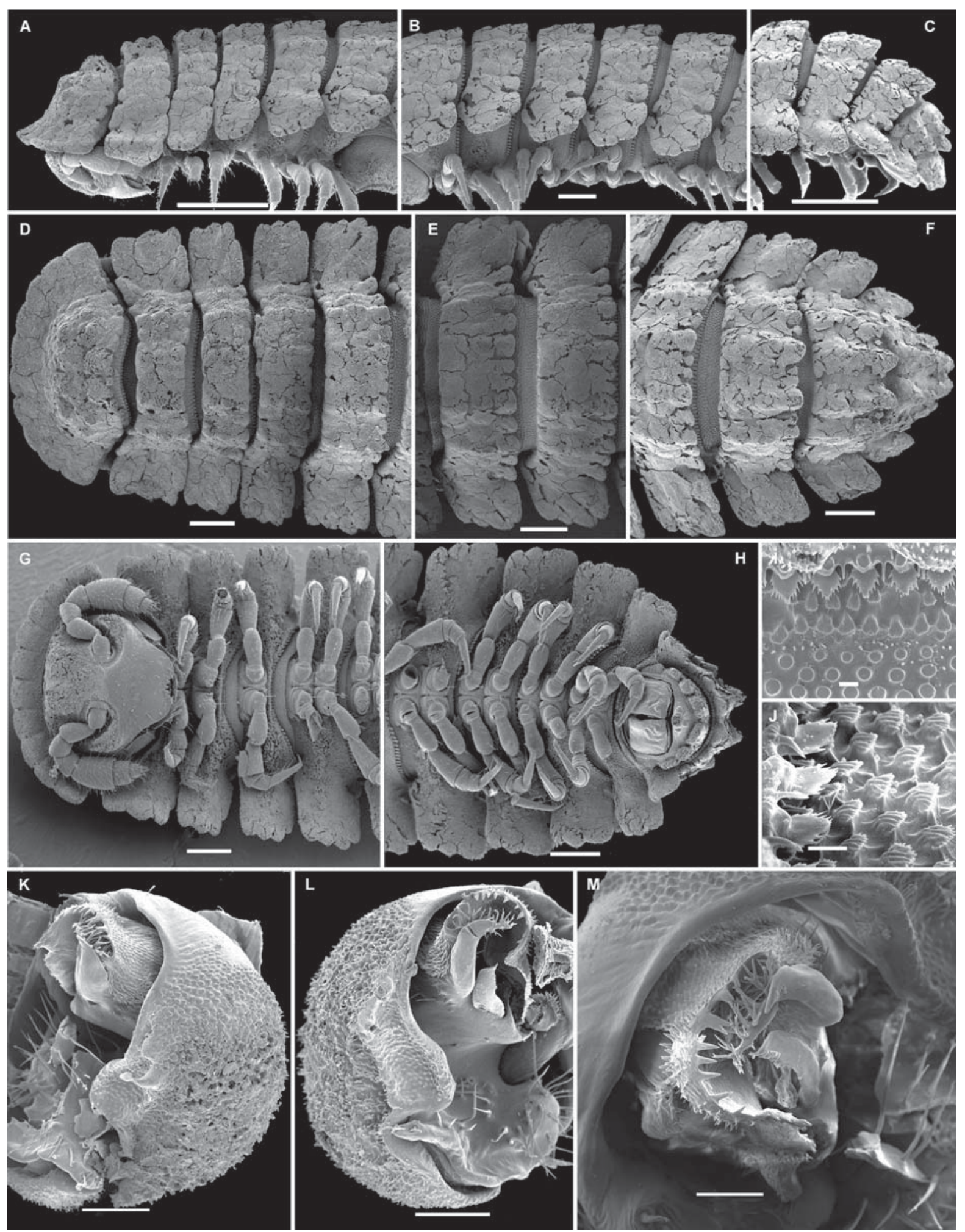

Fig. 3. SEM micrographs of Nonnodesmus niger Attems, 1953, $0^{7}$ from Ruwenzori: A, D \& G - anterior part of body, lateral, dorsal and ventral views, respectively; B \& E - midbody segments, lateral, and dorsal views, respectively; C, F \& H — posterior part of body, lateral, dorsal and ventral views, respectively; I \& J - limbus and adjacent microstructures; K-M - gonopods, ventral views. Scale bars: $0.5(\mathrm{~A}, \mathrm{C}), 0.2(\mathrm{~B}, \mathrm{D}-\mathrm{H}), 0.1(\mathrm{~K}-\mathrm{M}) \& 0.01 \mathrm{~mm}(\mathrm{I}, \mathrm{J})$.

Рис. 3. СЭМ-микрографии Nonnodesmus niger Attems, 1953, О7 из Рувензори: А, D, G - передняя часть тела, соответственно сбоку, сверху и снизу; В, Е - среднетуловищные сегменты, соответственно сбоку и сверху; C, F, H - задняя часть тела, соответственно сбоку, сверху и снизу; I и J - лимбус и соседние микроструктуры; K-M — гоноподы, снизу. Масштаб: 0,5 (А, C), $0,2(\mathrm{~B}, \mathrm{D}-\mathrm{H}), 0,1(\mathrm{~K}-\mathrm{M})$ и 0,01 мм (I, J). 


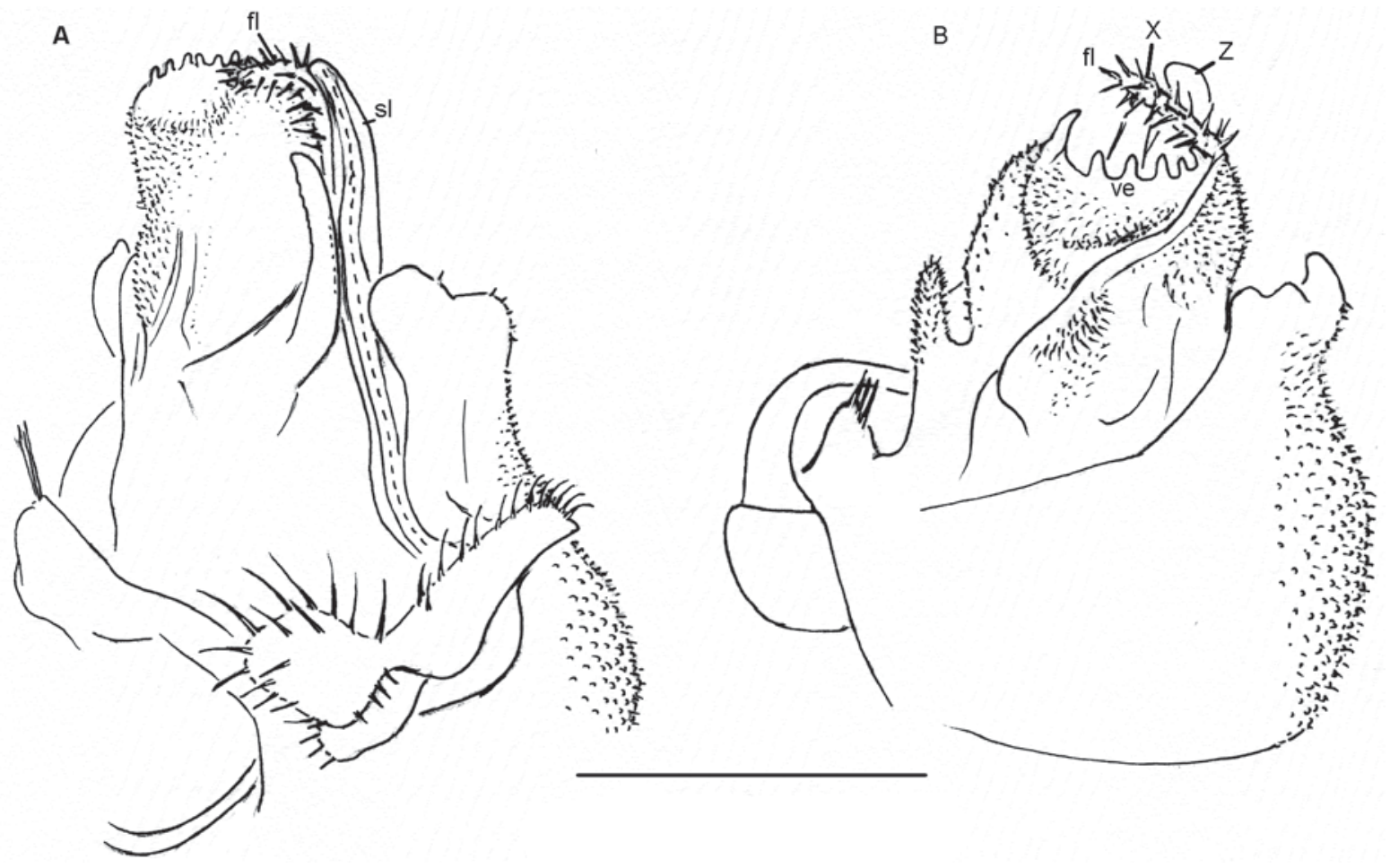

Fig. 4. Gonopods of Nonnodesmus niger Attems, 1953, $\mathrm{O}^{\top}$ from Ruwenzori, anterior and sublateral views, respectively. Scale bar 0.2 $\mathrm{mm}$. Designations in text.

Рис. 4. Гоноподы Nonnodesmus niger Attems, 1953, О7 из Рувензори, соответственно спереди и почти сбоку, Масштаб 0,2 мм. Обозначения в тексте.

Schouteden; $1 O^{\top}$ (MRAC 18645), Guinea, Forêt Classée de Ziama, pitfall traps, 29.IX.1999; 1 O$^{7}$ (MRAC 18510), same locality, 26.VII 1999; 1 \& (MRAC 18770), same locality, 23.X.1999, all leg. D. Flomo; $10^{2}, 1$ + (MRAC SN/12/269), Guinea, Mt. Nimba, Bangala Forest, $\mathrm{N} 07^{\circ} 39^{\prime}$, W $008^{\circ} 26^{\prime}$, $609 \mathrm{~m}$ a.s.l., humid litter, Winkler extraction, 7.III.2012, leg. A. Henrard, C. Allard, P. Bimou \& M. Sidibé; 1 q (MRAC 21758), Cameroon, Atlantic Mountains, litter among rocks, sieving, 30.IV.2007, leg. R. Jocqué, K. Loosveldt, L. Baert \& M. Alderweireldt.

REMARKS. This is the type species of an oligotypic genus, Stylodesmus Cook, 1895, which currently contains two more species only [Silvestri, 1927; Mauriès, Maurin, 1981]. Even though S. horridus has very nicely been redescribed from type material by Hoffman [1958], we provide additional illustrations to document the identity of the new samples (Fig. 5).

Although the series MRAC 11176-11177 was designated as containing paratypes, this was obviously a mistake. Firstly, Cook [1895, 1896a, b] had never designated holotypes to oppose them to paratypes in his descriptions, including those of $S$. horridus. Secondly, it is only due to Hoffman [1958] that we know that the type series of that species contained numerous specimens which he termed topotypes. Therefore, it is quite safe to believe that MRAC hosts a couple of syntypes, as, to the best of our knowledge, no lectotype selection has ever been made.

\section{Cachania Schubart, 1955}

The genus Cachania Schubart, 1955 has hitherto remained monobasic, C. placida Schubart, 1955 being the sole, and type, species [Schubart, 1955]. This genus had been treated as a member of what is currently accepted to be the family Trichopolydesmidae, apparently on account of the presence of metatergal setae and areations [Schubart, 1955; Hoffman, 1980], until Mauriès \& Maurin [1981] formally transferred Cachania to Pyrgodesmidae, albeit terming it a "cryptodesmiform" pyrgodesmid. Indeed, the flabellate collum covering most of the head from above, coupled with the typical tegument microstructure to support a metatergal cerategument, and the enlarged globose gonopod coxae showing a well-developed gonocoel for the accommodation of most of the telopodites, confirm that assignment.

Prompted by the discovery of three further Cachania species, we take the opportunity to review and rediagnose that interesting small genus indeed combining the characters of Pyrgodesmidae, Trichopolydesmidae and Cryptodesmidae.

NEW DIAGNOSIS. A genus of Pyrgodesmidae with 20 body segments in both sexes. Metatergal microsculpture typical of Pyrgodesmidae, with microvilli supporting a cerategument. Head roundish, smooth, without vertigial granulations; genae square. Antennae medium-sized, clavate, with usual apicodorsal groups of sensilla on antennomeres 5 and 6. Body polydesmoid or cryptodesmoid, with very broad, subhorizontal, wing-shaped paraterga set at about body midheight; collum flabellate, very wide, covering most of the head 

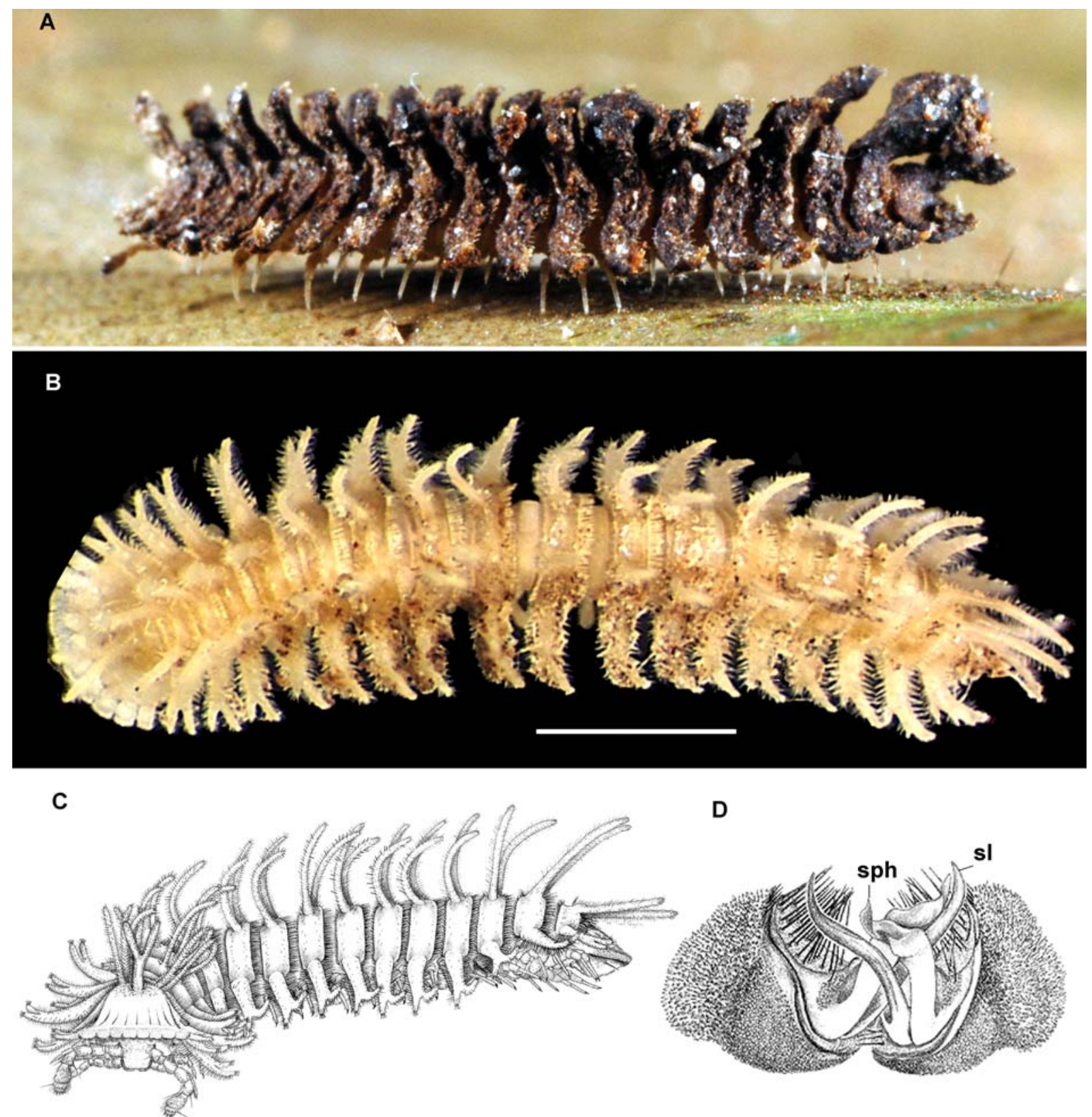

D

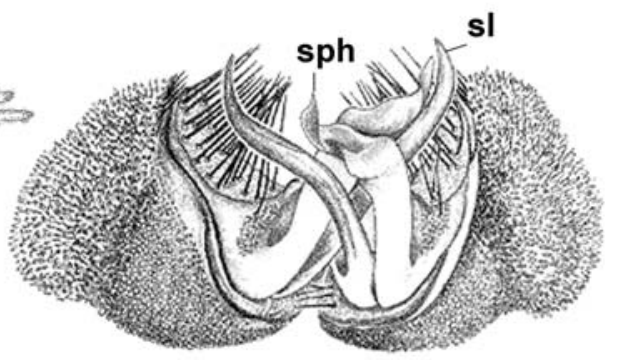

Fig. 5. Stylodesmus horridus Cook, 1895, $\sigma^{7} \mathrm{O}^{7}$ from Mt. Nimba: A-C - habitus, lateral, dorsal and frontolateral views, respectively; D - gonopods in situ, ventral view. Picture A taken not to scale, drawings C \& D executed not to scale by N. Van Noppen. Scale bar 1.0 $\mathrm{mm}(\mathrm{B})$.

Pис. 5. Stylodesmus horridus Cook, 1895, О70 о с горы Nimba: A-C - общий вид, соответственно сбоку, сверху и одновременно спереди и сбоку; D - гоноподы in situ, снизу. Фото А сделана без масштаба, рисунки C и D без масштаба, выполнены N. Van Noppen. Масштаб 1,0 мм (B).

from above, neither lobulate nor striate anteriorly, but clearly trilobate at caudal margin; collum and all following paraterga with longer setae at lateral margins; middle parts of metaterga areated, with three transverse rows of polygonal (micro)setigerous bosses typical of Trichopolydesmidae and most of Cryptodesmidae, but paraterga also with three clear lobulations/ incisions at caudal margin like in many Pyrgodesmidae and some Cryptodesmidae. Pore formula normal: 5, 7,
9, 10, 12, 13, 15-19; ozopores located dorsally, opening flush on tergal surface, mostly lying equidistant from anterior, lateral and posterior margins of poriferous paraterga. Paraterga with three or four lateral marginal lobulations delimited by faint impressions/striae extending more medially in poreless and pore-bearing segments, respectively, marginal setae being located at two or three indentations in between. Epiproct well visible from above between ultimate paraterga. 

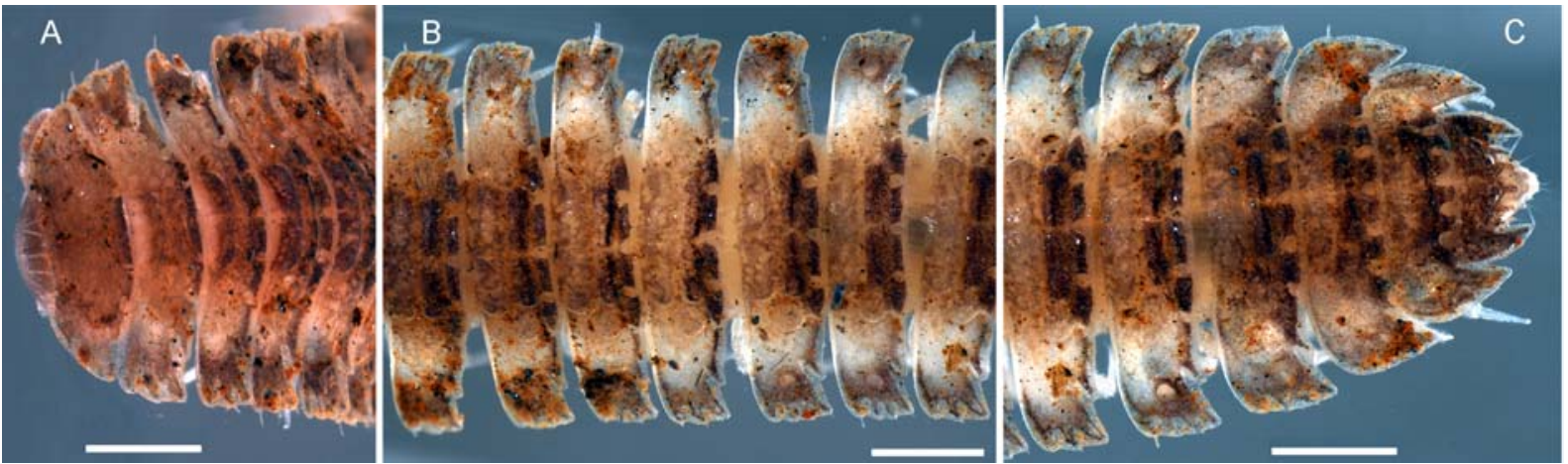

Fig. 6. Cachania spiniger sp.n., O paratype from Freton Forest: A-C — anterior, middle and caudal parts of body, respectively, dorsal view. Scale bars $0.5 \mathrm{~mm}$. Pictures taken by A. Henrard.

Рис. 6. Cachania spiniger sp.n., паратип О из леса Freton: A-C - соответственно передняя, средняя и задняя части тела, сверху. Масштаб 0,5 мм. Фото сделаны А. Henrard.
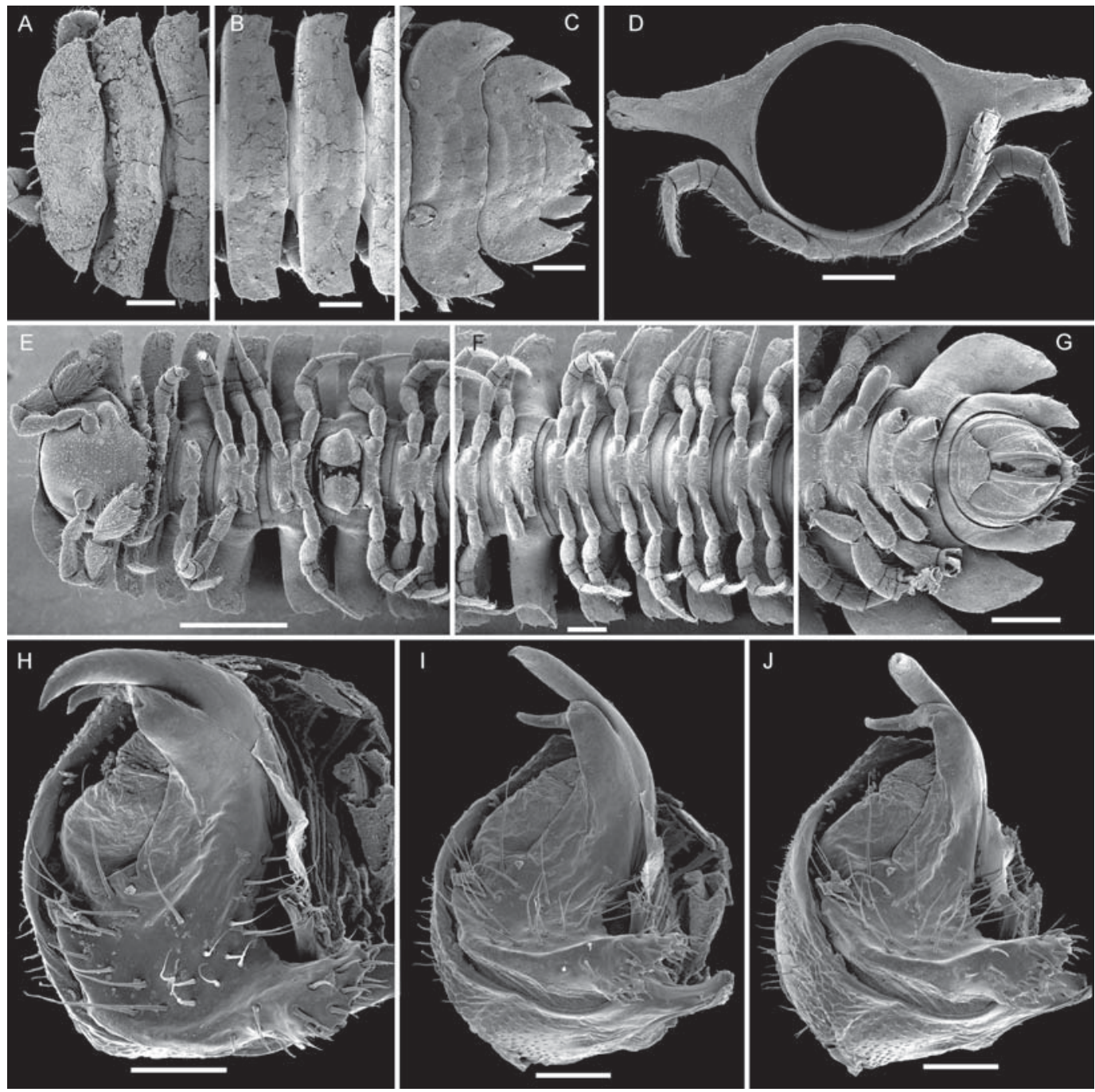

Fig. 7. SEM micrographs of Cachania spiniger sp.n., $\mathrm{O}^{7}$ paratype from Freton Forest: A \& E - anterior part of body, dorsal and ventral views, respectively; B \& F - middle part of body, dorsal and ventral views, respectively; C \& G — caudal part of body, dorsal and ventral views, respectively; D - cross-section of a midbody segment, caudal view; H-J — right gonopod, caudal, submesal and mesal views, respectively. Scale bars: $0.5(\mathrm{E}), 0.2(\mathrm{~A}-\mathrm{D}, \mathrm{F}, \mathrm{G}) \& 0.05 \mathrm{~mm}(\mathrm{H}-\mathrm{J})$.

Рис. 7. СЭМ-микрографии Cachania spiniger sp.n., паратип О७ из леса Freton: A, Е - передняя часть тела, соответственно сверху и снизу; В, F - средняя часть тела, соответственно сверху и снизу; C, G - задняя часть тела, соответственно сверху и снизу; D - поперечный срез через среднетуловищный сегмент, сзади; Н-J - правый гонопод, соответственно сзади, почти изнутри и изнутри. Масштаб: 0,5 (E), 0,2 (A-D, F, G) и 0,05 мм (H-J). 

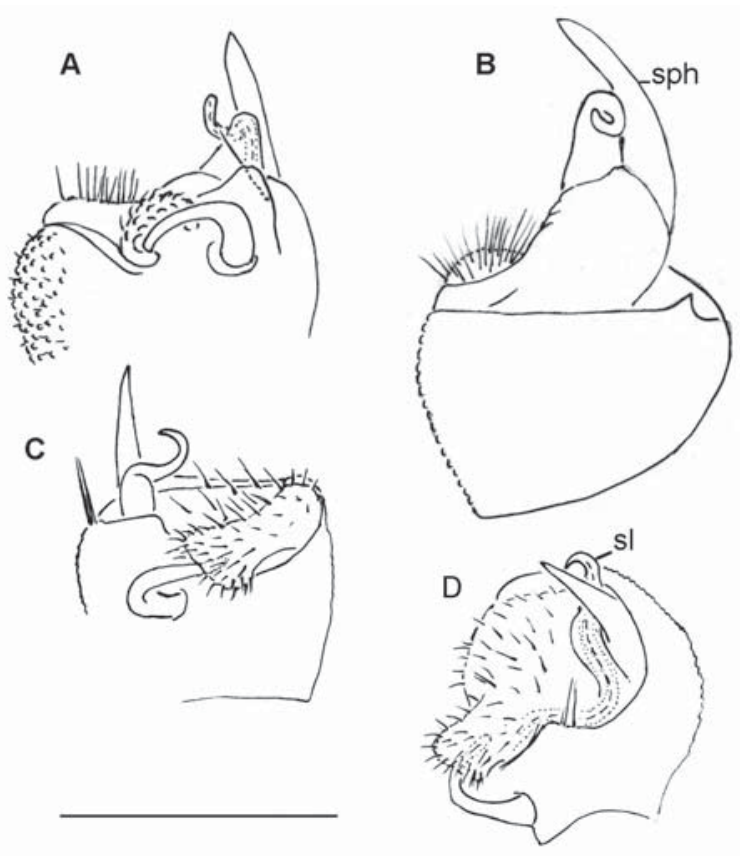

Fig. 8. Gonopods of Cachania spiniger sp.n., $\bigcirc^{7}$ paratype from Freton Forest (A, B) and Pierré Richard (C, D), mesal, lateral, mesal and anteroventral views, respectively. Scale bar $0.2 \mathrm{~mm}$. Designations in text.

Рис. 8. Гоноподы Cachania spiniger sp.n., паратип $\sigma^{7}$ из леса Freton (A, В) и из Pierré Richard (C, D), соответственно ихзнутри, сбоку, изнутри и одновременнл спереди и снизу. Масштаб 0,2 мм. Обозначения в тексте.

Sterna broad, ca 1.5 times the length of adjacent coxae, without modifications. Legs relatively long, extending well beyond lateral edges of paraterga, without modifications; tarsi only slightly longer than subequal prefemora and postfemora. Gonapophyses on $\sigma^{7}$ coxae 2 vestigial.

Gonopod aperture subcordiform, broad, about as wide as prozona 7. Gonopods rather simple; coxae subglobose, large, microgranulate and setose laterally, with usual long cannulae and a small, but evident apicolateral tooth; telopodites deeply sunken into a rather prominent gonocoel, only apical parts of deeply biramous, rather stout telopodites being exposed; each telopodite consisting of a shorter, simple, characteristically sigmoid solenomere (sl) protected laterally by a similarly simple, mostly somewhat higher, more or less lamellar solenophore (sph) (Figs 8, 10 \& 12).

Type species: Cachania placida Schubart, 1955, by original designation.

\section{Cachania spiniger sp.n.}

Figs 6-8.

HOLOTYPE $\sigma^{7}$ (MRAC 22649), Guinea, Mt. Nimba, Freton Forest, $\mathrm{N} 07^{\circ} 37^{\prime}$, W $008^{\circ} 29^{\prime}, 572 \mathrm{~m}$ a.s.1., soil \& litter, Winkler extraction, 10.III.2012, leg. A. Henrard, C. Allard, P. Bimou \& M. Sidibé.

PARATYPES: $2 \sigma^{\top}, 3$ 우 6 ㅇ subad. \& juv. (MRAC 22650), same data, together with holotype; $2 \sigma^{7} \sigma^{7}, 13$ o 9 (MRAC 22652), 1 क (ZMUM 22437$)$, Mt. Nimba, Pierré Richard, under Adit (= cave), sieving, 8.X.2011, leg. D. VandenSpiegel.
NAME. To emphasize the spiniform solenophore, a noun in apposition.

DIAGNOSIS. Differs by the brownish coloration, smaller size and spiniform solenophore. See also Key below.

DESCRIPTION. Length ca 5-5.5 $\left(\sigma^{7}\right)$ or $6.5-7.0$ $\mathrm{mm}(+)$, width of midbody pro- and metazonae $0.7-$ 0.75 and $1.4-1.5 \mathrm{~mm}\left(\sigma^{7}\right)$ or $0.8-1.0$ and $1.6-1.8 \mathrm{~mm}$ $(+)$, respectively. General coloration of dorsum in alcohol rather uniformly brown (Fig. 6), vertigial region, sometimes also lateral and caudal edges of metaterga clearly darkest; antennae, venter and legs yellowish to pallid.

In width, head $<$ collum $=$ segment $2<3=15$; thereafter body gradually tapering towards telson. Head smooth, roundish, genae square; clypeolabral region very finely and densely setose, epicranial suture visible only in occipital region; interantennal isthmus about twice as large as diameter of antennal socket (Fig. 7E). Antennae medium-sized, clavate, with small compact apicodorsal groups of bacilliform sensilla on antennomeres 5 and 6; the latter the largest (Fig. 7E). Body polydesmoid or cryptodesmoid, with very broad, subhorizontal, wing-shaped paraterga set at about body midheight (Figs 6 \& 7A-G). Collum flabellate, rather smooth, very wide, covering most of the head from above, neither lobulate nor striate anteriorly, but clearly trilobate at caudal margin and carrying a row of $3+3$ long setae on minute knobs at anterior margin and $2+2$ similar setae more laterally. Metaterga only slightly convex, with a usual cerategument layer on top of microvilli; middle parts areated, with three transverse rows of very low, polygonal, (micro)setigerous bosses. Tergal setae at lateral edges of paraterga much longer than those subclavate, longitudinally ribbed, very short ones located in the middle of metaterga. Postcollum paraterga also with three clear lobulations/incisions at caudal margin, mostly subrectangular at anterior and posterior lateral corners, only in posterior body third inclined increasingly caudad and nearly sharp, with three or four weak, lateral, marginal lobulations delimited by faint impressions/striae extending more medially in poreless and pore-bearing segments, respectively, longer marginal setae being located at 2 or 3 indentations in between. Ozopores similar in size along entire body, located dorsally, opening flush on tergal surface, mostly lying equidistant from anterior, lateral and posterior margins of poriferous paraterga (Fig. 7A-C), only on a few posteriormost segments shifted increasingly caudolaterally (Fig. 7C). Epiproct well visible from above between ultimate paraterga (Fig. 7C \& G). Hypoproct rounded apically, with 1+1 caudal setae on evident knobs (Fig. $7 \mathrm{G})$.

Sterna broad, ca 1.5 times as wide as length of adjacent coxae, without modifications, sparsely setose (Fig. 7E-G). Epigynal ridge behind 0 coxae 2 very low, rounded on sides. Legs relatively long, extending well beyond lateral edges of paraterga, without modifications, very slightly slenderer in $q$ than in $\sigma^{7}$; tarsi 

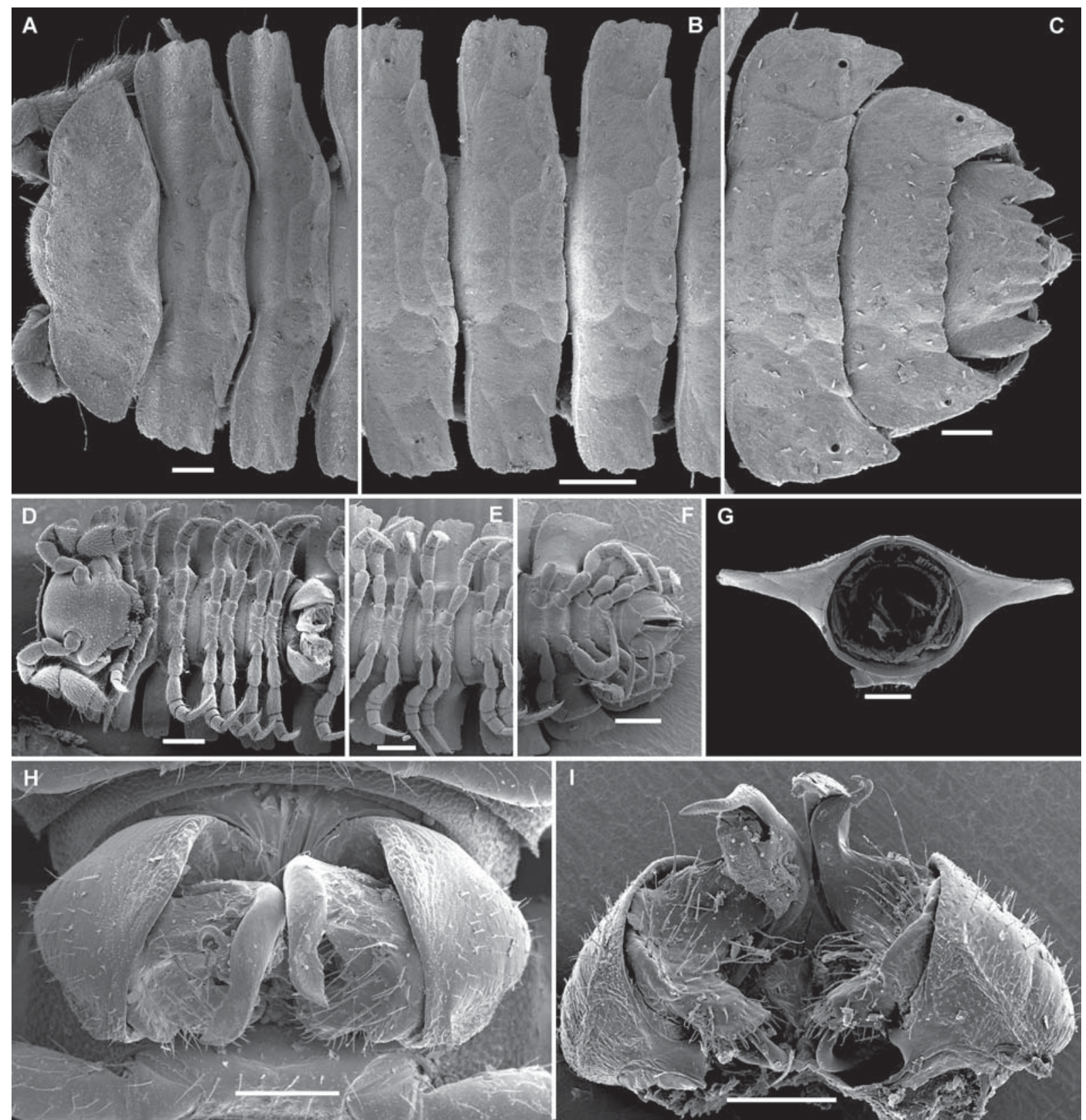

Fig. 9. SEM micrographs of Cachania taenia sp.n., O paratype: A \& D - anterior part of body, dorsal and ventral views, respectively; B \& E - middle part of body, dorsal and ventral views, respectively; C \& F - caudal part of body, dorsal and ventral views, respectively; $\mathrm{G}$ - cross-section of a midbody segment, caudal view; H \& I - both gonopods in situ, ventral and caudal views, respectively. Scale bars: $0.2(\mathrm{~B}, \mathrm{D}-\mathrm{F}) \& 0.1 \mathrm{~mm}(\mathrm{~A}, \mathrm{C}, \mathrm{G}-\mathrm{I})$.

Рис. 9. СЭМ-микрографии Cachania taenia sp.n., паратип О’: A, D — передняя часть тела, соответственно сверху и снизу; В, Е средняя часть тела, соответственно сверху и снизу; C, F — задняя часть тела, соответственно сверху и снизу; $\mathrm{G}$ - поперечный срез через среднетуловищный сегмент, сзади; H, I - оба гонопода in situ, соответственно снизу и сзади. Масштаб: 0,2 (B, D-F) и 0,1 мм (A, C, G-I).

only slightly longer than subequal prefemora and postfemora (Fig. 7E-G). Gonapophyses on $\sigma^{7}$ coxae 2 vestigial (Fig. 7E).

Gonopod aperture subcordiform, broad, about as wide as $\sigma^{7}$ prozona 7 (Fig. 7E). Gonopods (Fig. 7E, H$\mathrm{J} \&$ 8) rather simple; coxae subglobose, large, microgranulate and setose laterally, with usual long cannulae and a small, but evident apicolateral tooth; telopodites deeply sunken into a rather prominent gonocoel, only apical parts of deeply biramous, rather stout telopodites being exposed; each telopodite consisting of a shorter, simple, characteristically sigmoid solenomere (sl) protected laterally by a similarly simple, mostly somewhat higher, more or less lamellar solenophore (sph).

REMARK. This species occurs syntopically at least with C. furcata sp.n. 


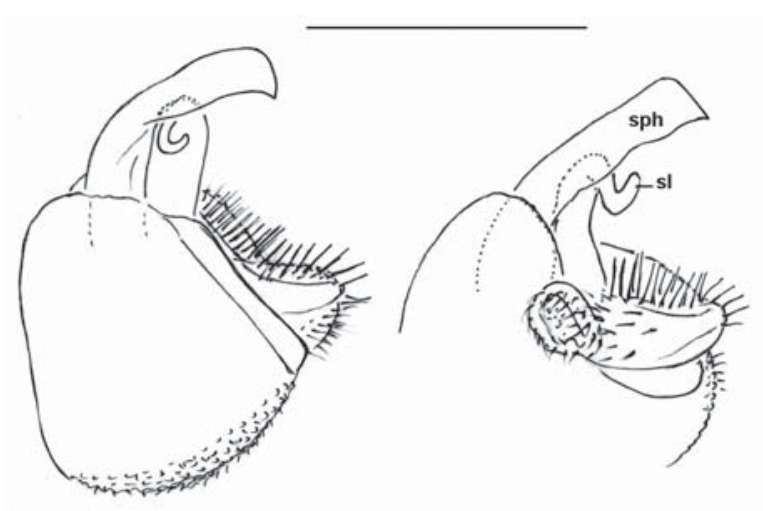

Fig. 10. Gonopods of Cachania taenia sp.n., O paratype, lateral (A) and mesal (B) views, respectively. Scale bar $0.2 \mathrm{~mm}$. Designations in text.

Рис. 10. Гоноподы Cachania taenia sp.n., паратип О', соответственно сбоку (А) изнутри (В). Масштаб 0,2 мм. Обозначения в тексте.

\section{Cachania taenia sp.n.}

Figs 9, 10.

HOLOTYPE $\sigma^{7}$ (MRAC 22637), Guinea, Mt. Nimba, Bangala Forest, $\mathrm{N} 07^{\circ} 39^{\prime}$, W $008^{\circ} 26^{\prime}, 609$ m a.s.l., soil \& litter, Winkler extraction, 7.III.2012, leg. A. Henrard, C. Allard, P. Bimou \& M. Sidibé.

PARATYPES: $5 \sigma^{\top} \sigma^{\top}, 16$ 우, 4 juv. (MRAC 22638), $1 \sigma^{\top}, 1$ 옹 (ZMUM 22438 ), same data, together with holotype; $22 \sigma^{7} \sigma^{7}, 28$ of, 13 juv. (MRAC 22639), same data, Winkler extraction, humid litter, 7.III.2012, leg. A. Henrard, C. Allard, P. Bimou \& M. Sidibé

NAME. To emphasize the ribbon-shaped solenophore.

DIAGNOSIS. Differs by the solenophore being ribbon-shaped.

DESCRIPTION. Length 4.5-6.0 mm, width of midbody pro- and metazonae $0.5-0.8$ and $1.1-1.6 \mathrm{~mm}\left(\sigma^{7}\right.$, $)$, respectively, usually $\sigma^{\top}$ being a little smaller than $q$. Coloration entirely pallid to brownish on dorsum, pattern as in C. spiniger sp.n., but without darker spots on vertex.

All characters as in C. spiniger sp.n. (Fig. 9A-G), except gonopods (Figs 9H, I \& 10) showing a rather large and clearly ribbon-shaped solenophore (sph).

REMARK. This species occurs syntopically at least with C. furcata sp.n.

\section{Cachania furcata sp.n.}

$$
\text { Figs 11, } 12 .
$$

HOLOTYPE $O^{7}$ (MRAC 22640), Guinea, Mt. Nimba, Freton Forest, $\mathrm{N} 07^{\circ} 37^{\prime}$, W $008^{\circ} 29^{\prime}$, $572 \mathrm{~m}$ a.s.l., soil \& litter, Winkler extraction, 10.III.2012, leg. A. Henrard, C. Allard, P. Bimou \& M. Sidibé.

PARATYPES: $1 \sigma^{7}, 4$ ㅇ (MRAC 22641), same data, together with holotype; $2 O^{\top} \sigma^{\top}$ (MRAC 22642), Guinea, Mt. Nimba, Bangala Forest, $\mathrm{N} 07^{\circ} 39^{\prime}$, W $008^{\circ} 26^{\prime}, 609$ m a.s.l., soil \& litter, Winkler extraction, 7.III.2012; 2 O $^{7} \sigma^{7}, 1$ क (ZMUM $\rho 2439$ ), same data, Winkler extraction, humid litter, 7.III.2012; $9 \sigma^{7} \sigma^{7}, 1$ ․, 1 juv. (MRAC 22643), Mt. Nimba, Seringbara Parking, N 07³8', W $008^{\circ} 27^{\prime}, 586 \mathrm{~m}$ a.s.1.,1. secondary forest, soil \& litter, Winkler extraction, 2-4.I.2012; 3 O $^{\top} \mathrm{O}^{7}, 4$ 우, 1 juv. (MRAC 22644), same data, all leg. A. Henrard, C. Allard, P. Bimou \& M. Sidibé.
NAME. To emphasize the bifurcate solenophore.

DIAGNOSIS. Differs by the nearly or entirely light coloration, a little larger size and the bifurcate solenophore.

DESCRIPTION. Length 7-9 mm $\left(\sigma^{7},+\right.$ ), width of midbody pro- and metazonae $1.0-1.1$ and $1.8-1.9 \mathrm{~mm}$ $\left(\sigma^{7}\right)$ or $1.3-1.4$ and $2.2-2.3 \mathrm{~mm}(+)$, respectively. Coloration entirely pallid to, more rarely, only faintly brownish on dorsum.

All characters as in $C$. spiniger sp.n. (Fig. 11A-I), except gonopods (Figs 11J-L \& 12) with a very prominent and clearly bifurcate solenophore (sph).

REMARKS. C. placida Schubart, 1955 was first found on Mount Nimba, which lies at the frontier between Liberia, Côte d'Ivoire and Guinea, and on Mount Tonkoui, Côte d'Ivoire, in primary tropical forests at 900-1200 m a.s.1. [Schubart, 1955]. This species was later refound on the same mountains [Demange \& Mauriès, 1975] and then reported also from Téké Forest, Côte d'Ivoire [Mauriès, Maurin, 1981]. Since no fresh samples of this species have been revealed in our material, we suspect that at least some of the numerous topotypes reported from Mt. Nimba by Demange \& Mauriès [1975] may actually represent at least some of the above new congeners. This invites revision of that old material.

The following key can be proposed for separating all four species of Cachania:

1(2) Ozopores on segments 5, 7, 9, 10, 12, 13-15 considerably larger than on following segments 16-19. Solenomere and solenophore about equal in length, solenophore also being less strongly sclerotized.... C. placida

2(1) Ozopores on all poriferous segments subequal in size. Solenophore always considerably longer than solenomere, both being equally strongly sclerotized ............ 3

3(4) Tip of solenophore widely bifurcate (Figs 11K, L \& 12) C. furcata sp.n.

4(3) Tip of solenomere not furcate, subtruncate or subacuminate ....

5(6) Solenophore ribbon-shaped and subtruncate at tip (Fig. 9H, I \& 10) ......................................... C. taenia sp.n.

6(5) Solenophore finger-shaped and subacuminate (Figs 7H$\mathrm{J} \& \mathrm{8})$.................................................. C. spiniger sp.n.

\section{Udodesmus Cook, 1896}

$=$ Hercodesmus Cook, 1896, syn.n.,

= Euhercodesmus Schubart, 1955, syn.n.

The small genus Udodesmus Cook, 1896 has hitherto been known to comprise only three species: $U$. telluster Cook, 1896, the type species beautifully redescribed from type material from Liberia by Silvestri [1927], U. guineae Silvestri, 1927 from Guinea [Silvestri, 1927], and U. tekeanus Mauriès et Maurin, 1981 from Côte d'Ivoire [Mauriès, Maurin, 1981]. Similarly, the genus Hercodesmus Cook, 1896 contains three species only: $H$. aureus Cook, 1896, the type species very nicely redescribed from type material from Liberia by Silvestri [1927], H. caudatus Silvestri, 1927 from Guinea [Silvestri, 1927], and H. subaureus Mauriès \& 

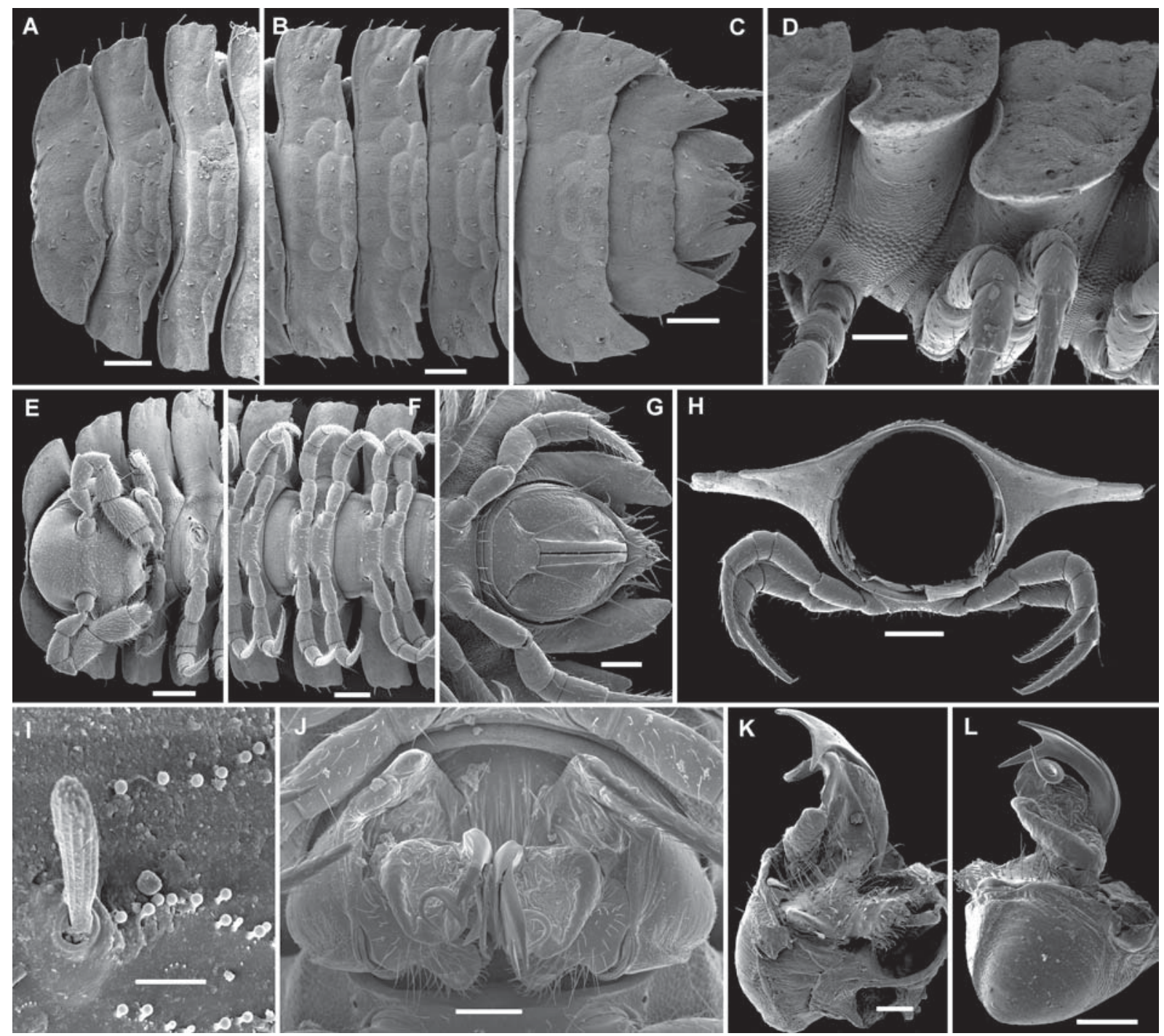

Fig. 11. SEM micrographs of Cachania furcata sp.n., $0^{7}$ paratype from Bangala Forest: A \& E - anterior part of body, dorsal and ventral views, respectively; B, D \& F - middle part of body, dorsal, lateral and ventral views, respectively; C \& G — caudal part of body, dorsal and ventral views, respectively; $\mathrm{H}$ - cross-section of a midbody segment, caudal view; I — tergal seta and adjacent microvilli; $\mathrm{J}-$ both gonopods in situ, ventral view; K \& L — gonopods, mesal and lateral views, respectively. Scale bars: 0.2 (A-C, E-H), 0.1 (D, J, L), $0.05(\mathrm{~K}) \& 0.01 \mathrm{~mm}(\mathrm{~L})$

Рис. 11. СЭМ-микрографы Cachania furcata sp.n., паратип О из леса Bangala: A, E - передняя часть тела, соответственно сверху и снизу; В, D, F - средняя часть тела, соответственно сверху, сбоку и снизу; C, G — задняя часть тела, соответственно сверху и снизу; Н - поперечный срез через среднетуловищный сегмент, сзади; I - тергальная щетинка и соседние микровилли; $\mathrm{J}$ - оба гонопода in situ, снизу; K, L — гоноподы, соответственно изнутри и сбоку. Масштаб: 0,2 (A-C, E-H), 0,1 (D, J, L), 0,05 (K) и 0,01 мм (L).

Maurin, 1981 from Côte d'Ivoire [Mauriès, Maurin, 1981]. These genera together with their type species were first very briefly diagnosed [Cook, 1896a: 419] and then redescribed in more detail [Cook, 1896b: $262]$, both times on the same page and both times Udodesmus preceding Hercodesmus by just one paragraph. Already Silvestri [1927] noted these two genera as being especially similar, differing only in metatergal sculpture which is much better developed and more elaborate in Udodesmus compared to that in Hercodesmus. However, their gonopod structure is basically the same, i.e. a long and slender solenophore very strongly projecting beyond the quite small and globose coxae, coupled with a nearly as long and slender solenomere which branches off at the very base of the telopodite and is directed either more or less laterad to lie close to the solenophore or is held subrectangular to the solenophore and directed caudad. Based on this shared general plan of gonopod conformation and the paragraphlong priority of Udodesmus over Hercodesmus [Cook, 1896a], we do not hesitate to formally synonymize these genera.

Euhercodesmus Schubart, 1955 was erected for the sole, and type, species E. helvus Schubart, 1955, from 
Fig. 12. Gonopods of Cachania furcata sp.n., $\mathrm{O}^{7}$ paratype from Bangala Forest, mesal (A) and lateral (B) views, respectively. Scale bar $0.2 \mathrm{~mm}$. Designations in text.

Рис. 12. Гоноподы Cachania furcata sp.n., паратип О из леса Bangala, соответственно изнутри (А) и сбоку (В). Масштаб 0,2 мм. Обозначения в тексте.
Mount Nimba, Guinea, based on the $q$ holotype [Schubart, 1955]. The obvious similarities to Hercodesmus spp. were reflected in the name of the new genus while the differences were noted in the number of body segments (19 vs. 20), a variable (2-3) number of larger mid-dorsal and dorsolateral tubercles on the main crests per metatergum along the body, as well as the much less strongly lobulate and tuberculate collum. Since the gonopod structure remained unknown, that was deemed sufficient to create the new monobasic genus.

Prompted by the discovery of two further Udodesmus species, we take the opportunity to review and rediagnose this genus, synonymizing it with Hercodesmus and Euhercodesmus, and providing a key to all of its nine currently known species. The following new combinations are proposed: U. aureus (Cook, 1896), U. caudatus (Silvestri, 1827) and U. subaureus (Mauriès et Maurin, 1981), all three comb.n. ex Hercodesmus, as well as $U$. helvus (Schubart, 1955), comb.n. ex Euhercodesmus.

NEW DIAGNOSIS. A genus of Pyrgodesmidae with 19 or 20 body segments. Metatergal microsculpture typical of Pyrgodesmidae, with microvilli supporting a cerategument. Head roundish, with vertigial granulations; genae with a deep groove for accommodation of antennae. Antennae short, clavate, antennomere 5 larger than $6^{\text {th }}$, each with an apicodorsal group of bacilliform sensilla. Paraterga set low (at about lower 1/3 body height). Collum flabellate, often capuchin-shaped, entirely covering the head from above, always with clearly differentiated lobulations at anterior margin, centrally often with differentiated tubercles as well. Postcollum metaterga with usual larger mid-dorsal and dorsolateral tubercles in $2+2$ paramedian crests, each crest with 2-3 transverse rows of evident to poorly expressed tubercles; paraterga 2 trilobate, following ones bilobate at lateral margin; anterolateral lobulations wanting, but a few caudolaterals sometimes present; all paraterga strongly declined ventolaterad, reaching down to level of sterna. Pore formula usually normal: $5,7,9,10,12,13,15-18(19)$, porosteles if any very short, ozopores located either between both lateral lobulations or on caudal lobulation near lateral margin. Tergal setae absent. Epiproct fully hidden under penultimate segment.

Sterna narrow, much less than length of coxa, deeply impressed along main axis of body, without modifi-

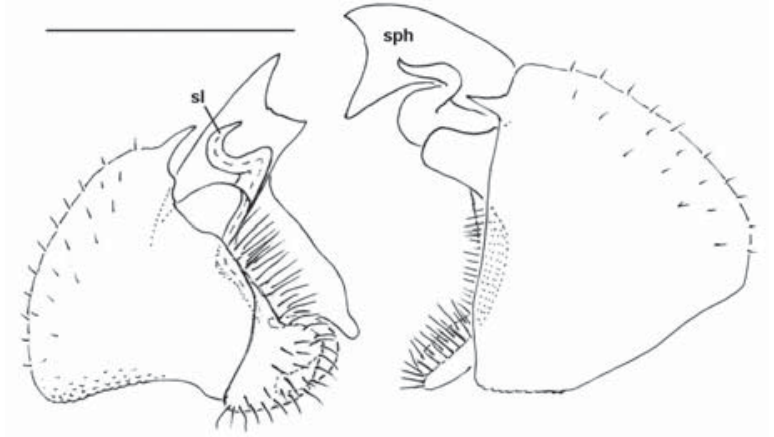

cations. Legs relatively short, barely extending beyond lateral edges of paraterga, without modifications; prefemora longest. Gonapophyses on $\sigma^{7}$ coxae 2 vestigial.

Gonopod aperture subcordiform, broad, nearly or about as wide as $\sigma^{7}$ prozona 7 . Gonopods rather simple; coxae subglobose, moderately large, microgranulate and microsetose laterally, with usual long cannulae and usually a small, but evident apicoventral tubercle; very long and slender telopodites unusually strongly exposed, partly also due to a small gonocoel, both or only their solenophores (sph) directed mesad and strongly crossing each other; each telopodite deeply biramous, consisting of a shorter, usually more simple solenomere (sl) held either subparallel or subrectangular (directed caudad) to a longer, normally more elaborate sph (Figs 15 \& 17D-F).

Type species: U. telluster Cook, 1896, by monotypy.

\section{Udodesmus harpago sp.n.}

Figs 13-15.

HOLOTYPE $\sigma^{7}$ (MRAC 22645), Guinea, Mt. Nimba, Seringbara Parking, $\mathrm{N} 07^{\circ} 38^{\prime}$, W $008^{\circ} 27^{\prime}$, $586 \mathrm{~m}$ a.s.1., secondary forest, soil \& litter, Winkler extraction, 2-4.I.2012, leg. A. Henrard, C. Allard, P. Bimou \& M. Sidibé.

PARATYPES: 1 \%, 3 우, 6 juv. (MRAC 22646), same data, together with holotype; $1 \sigma^{7}, 8$ क 9 , 4 juv. (MRAC 22647), $1 \sigma^{7}, 1$ (ZMUM 2440 ), same data; $1 \sigma^{7}, 1$ क, 1 juv. (MRAC 22648), Guinea, Mt. Nimba, Newenè, N 0741', W 008 $26^{\prime}$, $545 \mathrm{~m}$ a.s.1., dry litter, Winkler extraction, 25.II.2012, all leg. A. Henrard, C. Allard, P. Bimou \& M. Sidibé.

NAME. The species name harpago means harpoon in Latin, a noun in apposition, to emphasize the shape of the solenophore.

DIAGNOSIS. Differs by the harpoon-shaped solenophore. See also Key below.

DESCRIPTION. Length of adults ca 5-5.5 $\left(\mathrm{O}^{7}\right)$ or 6.5-7.5 $\mathrm{mm}(+)$, width of midbody pro- and metazonae $0.8-1.0$ and $1.1-1.5 \mathrm{~mm}\left(\sigma^{\top},+\right)$, respectively. Metaterga together with paraterga in alcohol (light) brown to blackish brown (Fig. 13), prozonae, venter and legs yellowish to pallid.

Body with 20 segments, tegument dull. In width, head $<$ collum $=$ segment $2<3=15$; thereafter body gradually tapering towards telson. Head roundish, vertex distinctly microgranulate, clypeolabral region densely and finely setose, each gena with a very deep groove for accommodation of antenna, epicranial suture visi- 

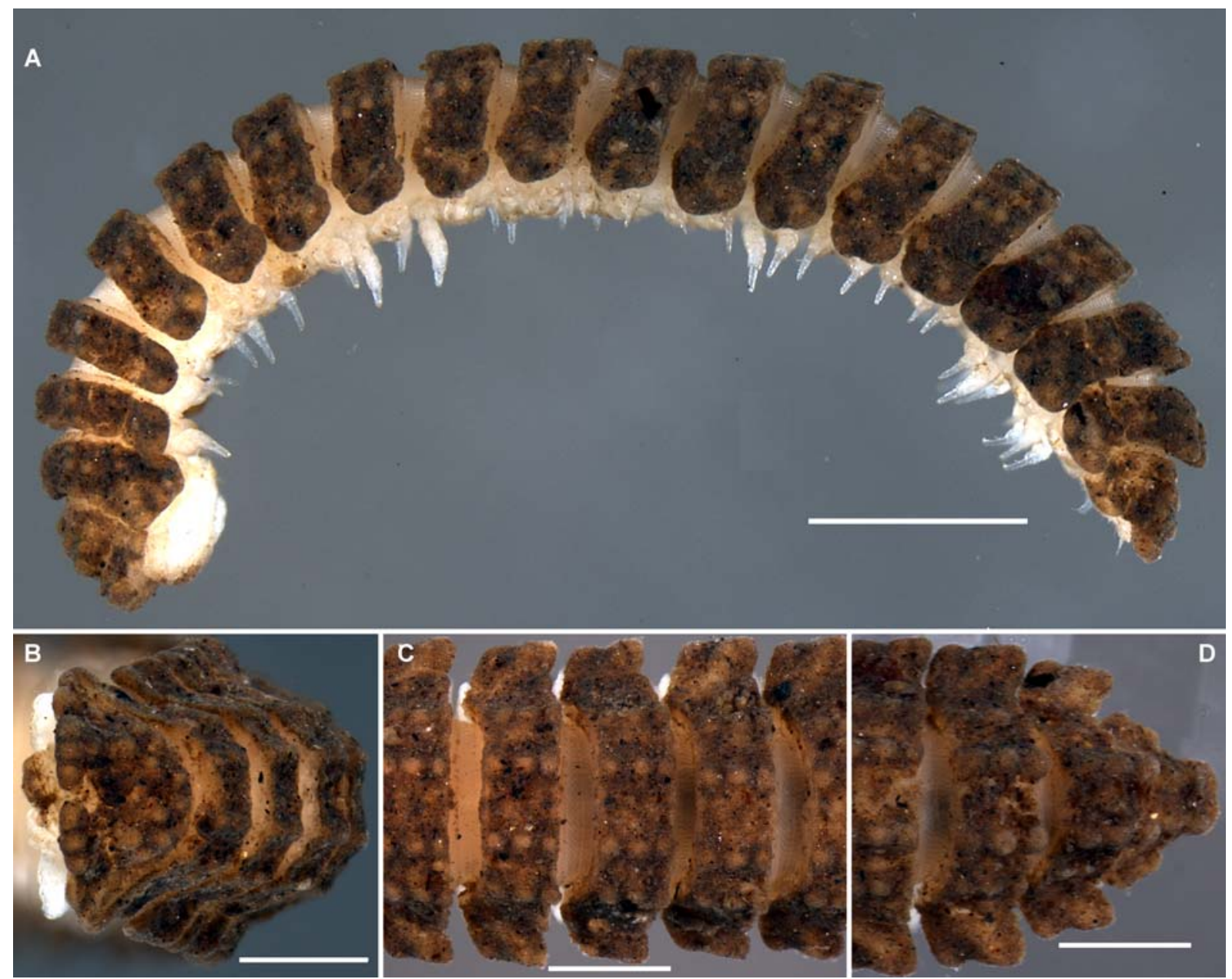

Fig. 13. Udodesmus harpago sp.n., O paratype from Seringbara Parking: A - habitus, lateral view; B — anterior part of body, frontal view; C \& D - middle and caudal parts of body, respectively, dorsal view. Scale bars: 1.0 (A) \& $0.5 \mathrm{~mm}$ (B-D). Pictures taken by A. Henrard.

Рис. 13. Udodesmus harpago sp.n., паратип О7 с парковки Seringbara: A - общий вид, сбоку; В - передняя часть тела, спереди; C, D - соответственно средняя и задняя части тела, сверху. Масштаб: 1,0 (А) и 0,5 мм (B-D). Фото сделаны А. Henrard.

ble only in occipital region; interantennal isthmus about twice as large as diameter of antennal socket (Fig. 14D \& E). Antennae very short, strongly clavate, with small compact apicodorsal groups of bacilliform sensilla on antennomeres 5 and 6; the former the largest (Fig. 14D). Collum fully covering the head from above, flabellate, somewhat capuchin-shaped, anterior margin somewhat elevated, with $5+3+3+5$ modest lobulations with small, but evident gaps between all four groups of lobules (Figs 13B \& 14E); paraterga strongly declined ventrolaterally (Figs 13A, 14A-C \& K), rounded on sides; middle part with $2+2$ and $2+2$ higher, paramedian, round tubercles arranged in two transverse rows and clearly divided by an impression mid-dorsally. Collum and following metaterga strongly convex, with a usual cerategument layer on top of microvilli, it being mostly hidden under a strong crust of reddish or redbrown earth. Stricture deep, texture microvillose like metaterga. Paramedian larger mid-dorsal (MD) and dorsolateral (DL) lobulations subequal, forming $2+2$ crests arranged in usual three transverse rows, increasingly prominent towards telson and considerably inclined caudad in segments 17-19 (Figs 13 \& 14A-K). Smaller mid-dorsals between MD, as well as between and below DL barely discernible due to heavy earth crust. Postcollum paraterga even more strongly declined ventrolaterally than on collum, reaching down to level of sterna (Fig. 14K), rounded, devoid of visible caudo- and anterolaterals; paraterga 2 somewhat enlarged, trilobate, their caudal halves clearly skewed ventrad, this being the opposite in following paraterga; their lateral margin clearly, but not very deeply bilobate, both lobes being subequal in size and rounded. Pore formula probably normal, but untraceable due to earth crust extending to lateral margins as well; ozopores small, inconspicuous, not borne on porosteles, better visible in segments 15-19, lying dorsolaterally between both marginal lobes. Prozonae very finely microalveolate (Fig. 14L). Limbus microspiculate (Fig. 14L). Epiproct fully hidden under penultimate seg- 

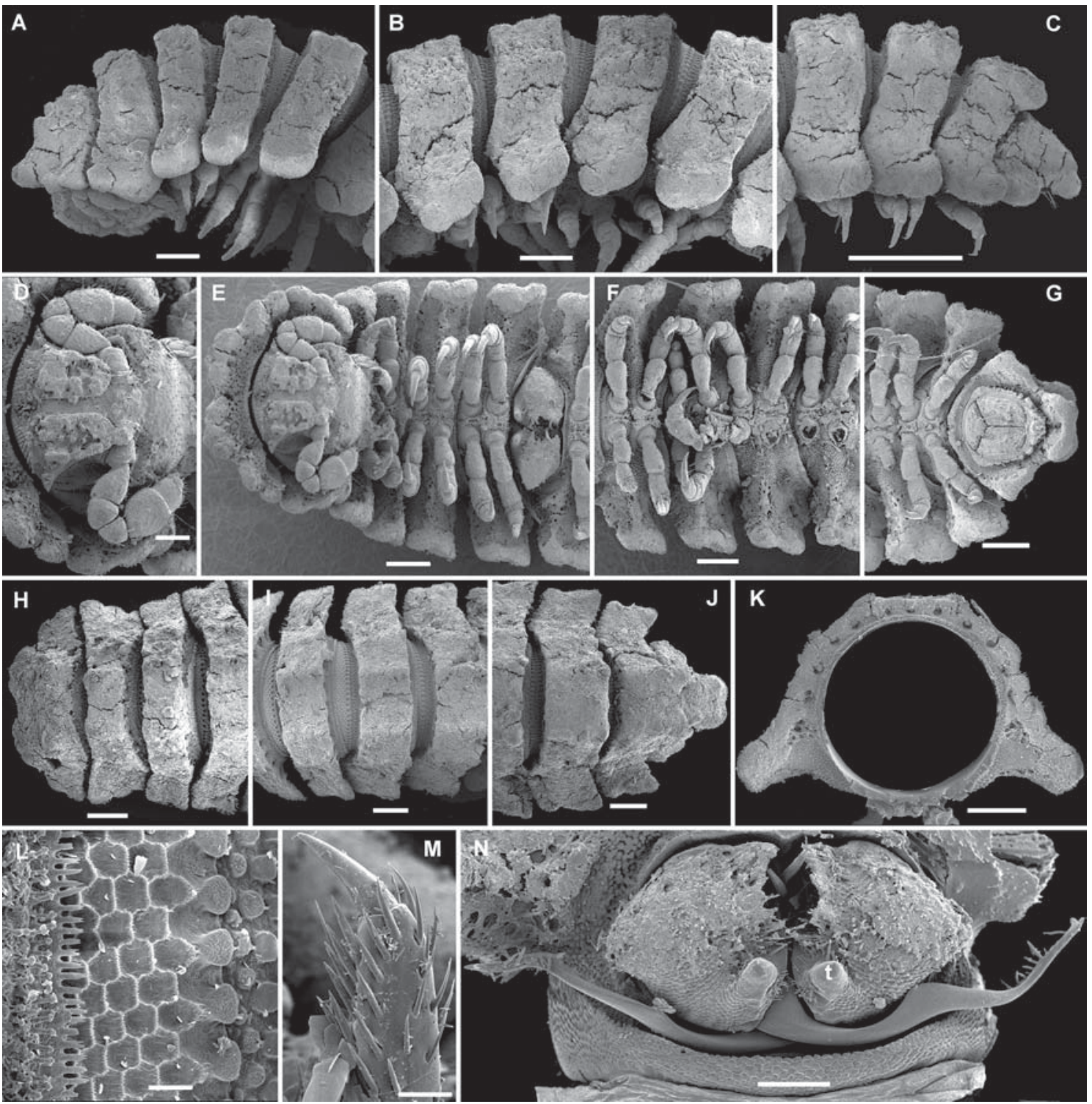

Fig. 14. SEM micrographs of Udodesmus harpago sp.n., $0^{7}$ paratype from Seringara Parking: A, E \& H - anterior part of body, lateral, ventral and dorsal views, respectively; B, F \& I - middle part of body, lateral, ventral and dorsal views, respectively; C, G \& J caudal part of body, lateral, ventral and dorsal views, respectively; D - head, ventral view; $\mathrm{K}$ - cross-section of a midbody segment, caudal view; $\mathrm{L}$ - limbus and adjacent microstructures; $\mathrm{M}$ - pregonopodial tarsus, lateral view; $\mathrm{N}$ - both gonopods in situ, ventral view. Scale bars: 0.5 (A), 0.2 (A, B, E-K), $0.1(\mathrm{D}, \mathrm{N}) \& 0.02 \mathrm{~mm}(\mathrm{~L}, \mathrm{M})$. Designations in text.

Рис. 14. СЭМ-микрографы Udodesmus harpago sp.n., паратип О7 с парковки Seringbara: A, E, H - передняя часть тела, соответственно сбоку, снизу и сверху; В, F, I - средняя часть тела, соответственно сбоку, снизу и сверху; С, G, J - задняя часть тела, соответственно сбоку, снизу и сверху; D - голова, снизу; K - поперечный срез через среднетуловищный сегмент, сзади; $\mathrm{L}$ - лимбус и соседние микроструктуры; M - лапка прегоноподиального ноги, сбоку; $\mathrm{N}$ - оба гонопода in situ, снизу. Масштаб: $0,5(\mathrm{~A}), 0,2(\mathrm{~A}, \mathrm{~B}, \mathrm{E}-\mathrm{K}), 0,1(\mathrm{D}, \mathrm{N})$ и 0,02 мм (L, M). Обозначения в тексте.

ment, the latter subtruncate caudally (Fig. 14C, G \& J). Hypoproct triangular (Fig. 14G).

Sterna narrow, clearly and deeply impressed along axis (Fig. 14E-G). Legs short and rather stout, $\sigma^{7}$ tarsi being especially densely setose (Fig. 14M).

Gonopod aperture subcordiform, taking up most of ventral part of $\sigma^{7}$ metazonite 7 (Fig. 14E). Gonopod coxae globose, densely micropapillate and microsetose laterally, each with a distinct caudoventral tubercle (t) on top (Fig. 14N); gonocoel small, telopodites very strongly exposed, directed mesad, in situ crossing each other (Fig. 14N); solenophore (sph) especially long and slender, only slightly curved, in distal $1 / 4$ with a row of barbs and an apical hook which all make sph look very much like a harpoon; solenomere (sl) another slender, slightly curved, apically unciform, simple and about half as long branch directed caudad (Figs $14 \mathrm{~N} \& 15)$ 


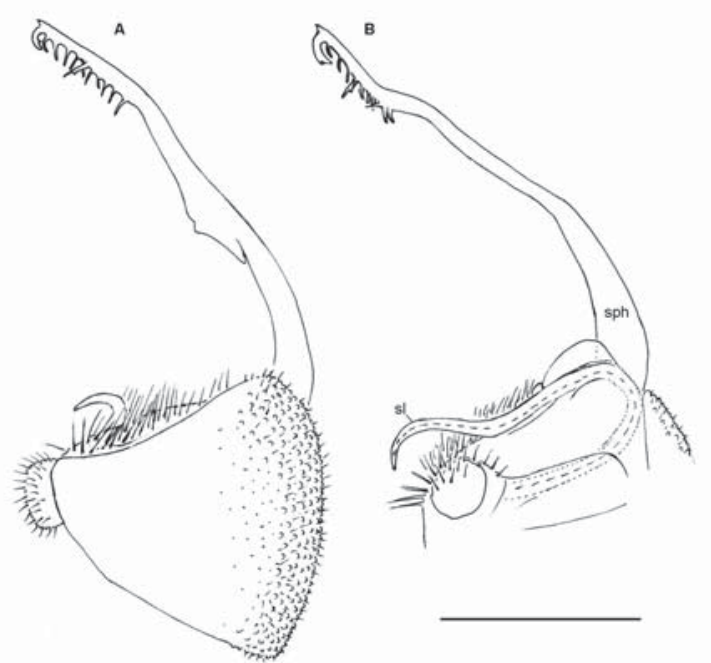

Fig. 15. Gonopods of Udodesmus harpago sp.n., $\sigma^{7}$ paratype from Seringara Parking, lateral (A) and mesal (B) views, respectively. Scale bar $0.2 \mathrm{~mm}$. Designations in text.

Рис. 15. Гоноподы Udodesmus harpago sp.n., паратип O c парковки Seringara соответственно сбоку (А) и изнутри (В). Масштаб 0,2 мм. Обозначения в тексте.

\section{Udodesmus liber sp.n.}

Figs 16, 17.

HOLOTYPE $\sigma^{7}$ (MRAC 22651), Liberia, Bong Range Forest, $\mathrm{N} 06^{\circ} 49^{\prime}$, W $010^{\circ} 17^{\prime}$, rainforest, pitfall traps, 3-24.X.2005, leg. D. Flomo.

NAME. To emphasize provenance from Liberia.

DIAGNOSIS. Differs by the bifid solenophore. See also Key below.

DESCRIPTION. Holotype in poor condition, damaged by fungal growth inside, but complete (Fig. 16). Length ca $4.5 \mathrm{~mm}$, width of midbody pro- and metazo- nae 0.4 and $0.5 \mathrm{~mm}$, respectively. Coloration uniformly very light yellowish brown, tegument transparent (Fig. 16).

All characters as in $U$. harpago sp.n., except as follows.

Collum fully covering the head from above, flabellate, anterior margin somewhat elevated, without distinct lobulations, but with two smaller lateral and one larger central lobe (Fig. 16B \& 17A); paraterga considerably declined ventrolaterally, rounded on sides; middle part with $2+2$ and $2+2$ higher, paramedian, round tubercles arranged in two transverse rows and clearly divided by an impression mid-dorsally (Fig. 17A). Collum and following metaterga strongly convex, together with strictures with a usual cerategument layer on top of microvilli, but devoid of a crust of earth. Paramedian larger mid-dorsal (MD) and dorsolateral (DL) tubercles subequal, forming $2+2$ narrow, rather low crests arranged in usual three transverse rows (Fig. 17B), increasingly prominent towards telson and considerably inclined caudad in segments 17-19. Postcollum paraterga even more strongly declined ventrolaterally than on collum, rounded, devoid of visible anterolaterals, but with two caudolaterals beneath DL3; lateral margin clearly, but not very deeply bilobate, both lobes being subequal in size and rounded (Fig. 17B). Pore formula untraceable due to invisible ozopores, the latter not borne on porosteles, likely lying dorsolaterally between both marginal lobes. Epiproct fully hidden below penultimate segment, the latter bilobed caudally (Figs 16B \& 17C).

Gonopod coxae subglobose, densely micropapillate and microsetose laterally, also each with a distinct caudoventral tubercle on top; gonocoel small, telopodites strongly exposed, directed mesad, in situ crossing each other (Fig. 17D-F); solenophore (sph) long and slender,
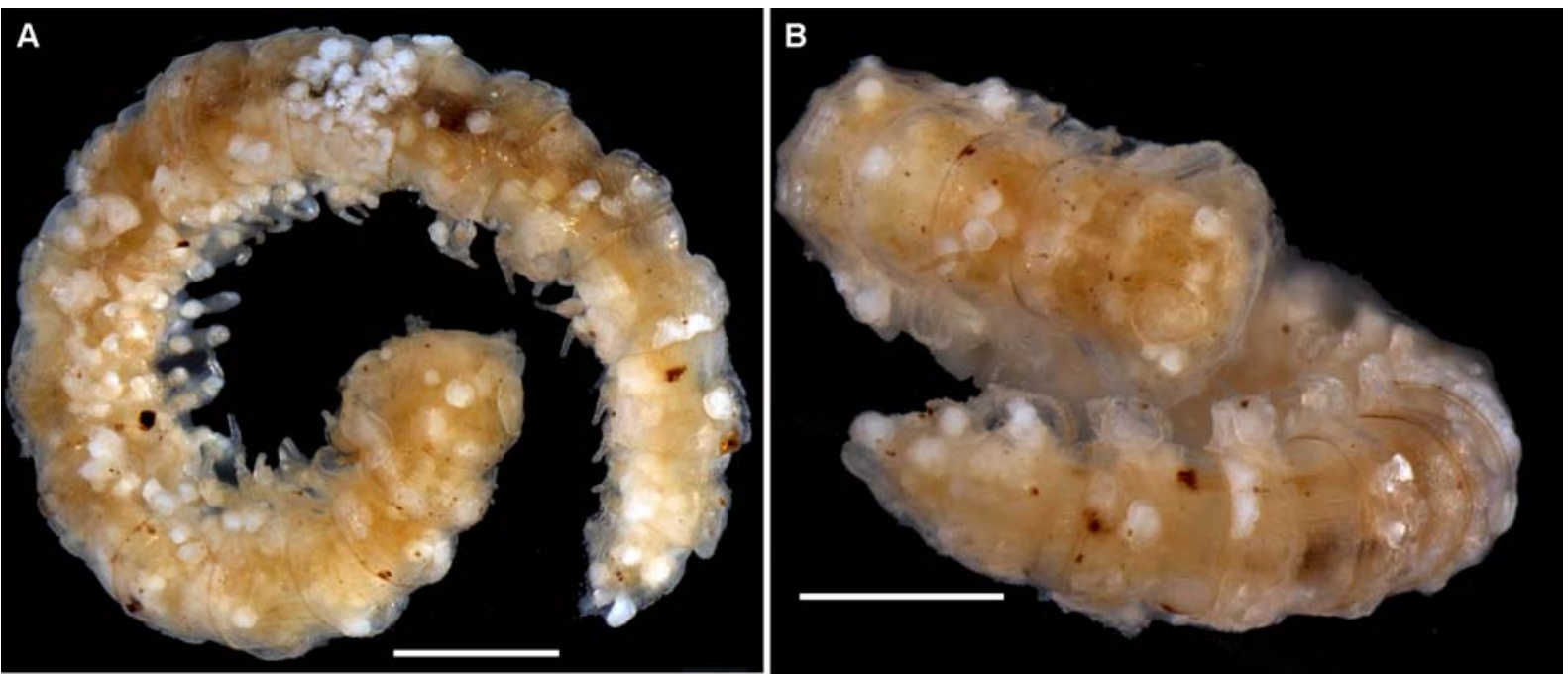

Fig. 16. Udodesmus liber sp.n., $\sigma^{7}$ holotype: A - habitus, lateral view; B - anterior and posterior parts of body, dorsal view. Scale bars $0.5 \mathrm{~mm}$. Pictures taken by A. Henrard.

Рис. 16. Udodesmus liber sp.n., голотип О’: А - общий вид, сбоку; В - передняя и задняя части тела, сверху. Масштаб 0,5 мм. Фото сделаны А. Henrard. 

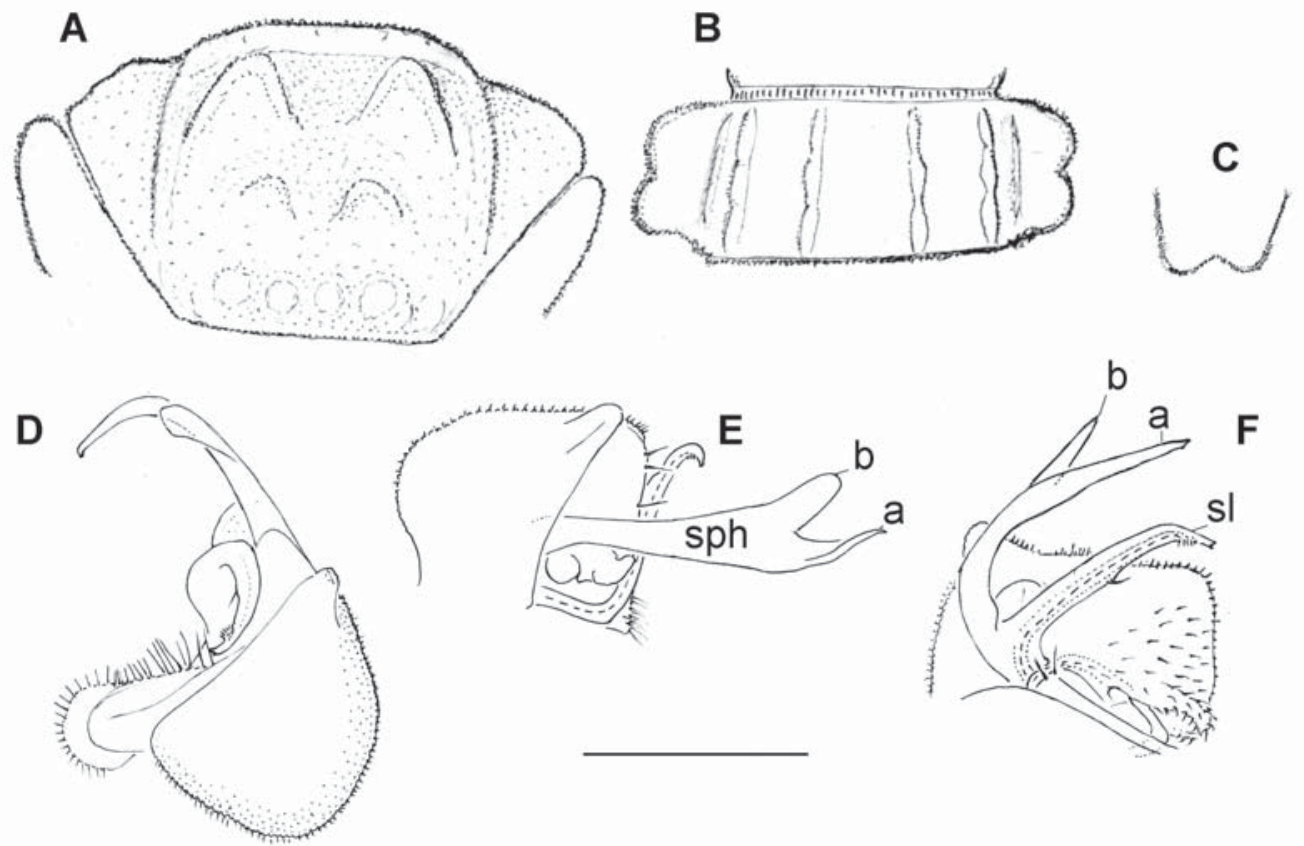

Fig. 17. Udodesmus liber sp.n., $\mathrm{O}^{7}$ holotype: A, B \& C - collum, midbody metatergum and tip of segment 19, respectively, dorsal view; D-F - gonopods, anterolateral, subventral and mesal views, respectively. Drawings A-C executed not to scale; scale bar $0.2 \mathrm{~mm}$ (D-F). Designations in text.

Рис. 17. Udodesmus liber sp.n., голотип О': А, В, С - соответственно коллум, среднетуловищный сегмент и задний конец сегмента 19, сверху; D-F - гоноподы, соответственно одновременно спереди и сзади, почти снизу и изнутри. Рисунки А-C сделаны без масштаба; масштаб 0,2 мм (D-F). Обозначения в тексте.

only moderately curved, in distal half bifurcate into a simple acuminate branch (a) and a shorter, spatuliform, rounded lobe (b); solenomere (sl) somewhat thicker than in $U$. harpago sp.n., also set subrectangular to $\mathbf{s p h}$, but with a small hairy pad marking the orifice of seminal groove subapically (Fig. 17D-F).

REMARKS. Despite the rather pronounced range of variation in peripheral (= somatic) characters, the genus Udodesmus remains quite well recognizable due to the typical pyrgodesmid facies (collum hiding the head from above, metatergal tuberculations differentiated, paraterga lobulated, epiproct fully hidden under penultimate segment etc.), the clearly differentiated lobulations at the anterior margin of the collum, the laterally bilobate paraterga, the presence of $2+2$ crests of larger MD and DL tubercles on the postcollum metaterga, the usually normal pore formula when the ozopores either open flush on dorsal or dorsolateral surface of poriferous paraterga or borne on very short porosterles at most. However, the genus seems to be best characterized by the very particular gonopod structure as described above in the emended generic diagnosis. In addition, all Udodesmus species show a quite coherent distribution pattern, being restricted to western Africa. In our opinion, Stylodesmus, another western African genus ranging from Liberia in the west to Cameroon in the east (see above), seems to be especially similar to Udodesmus, both sharing not only many of the above peripheral characters, but also deeply biramous and clearly exposed gonopods which are crossing mesally. In contrast to Udodesmus, however, the solenomere in Stylodesmus is longer than the solenophore.

The following key can be offered to separate all known Udodesmus species.

1(2) Marginal lobulations on collum weak to rather deep, but pattern always clear: $2+3+3+2$, gaps between all four groups being very deep, much deeper than incisions between lobulations proper. Penultimate segment usually very deeply notched caudally

2(1) Pattern of marginal lobulation on collum different or unclear, gaps between groups of lobulations being variable. Penultimate segment at most only faintly notched or concave (at most as in Fig. 17C)

3(4) Body with 19 segments (+). Lobulations on collum highly unequal, each of both lateral ones being much broader than each of $3+3$ frontalmost. MD and DL crests composed of three tubercles each only on segment 17 , all preceding ones until segment 2 of two tubercles...... U. helvus

4(3) Body with 20 segments. Lobulations on collum subequal. All postcollum metaterga with three transverse rows of tubercles in MD and DL crests

5(6) Body ca $12 \mathrm{~mm}$ long and $2.5 \mathrm{~mm}$ wide. Each group of frontalmost $3+3$ lobulations on collum skewed and lying subparallel to main axis. $2+2$ longitudinal crests of larger mid-dorsal and dorsolateral tubercles on postcollum metaterga arranged in two transverse rows until segment 15 , in three rows thereafter. Solenophore barbed apically. U. guineae 
6(5) Body at most $9 \mathrm{~mm}$ long and $1.8 \mathrm{~mm}$ wide $\left(\mathrm{O}^{7}\right)$. All marginal lobulations on collum subhorizontal. Pattern of MD and DL distribution along body different. Solenophore apex not barbed

7(8) Central tubercles on collum much shorter than very high marginal lobulations U. telluster

8(7) Central tubercles on collum nearly as high as marginal lobulations ... U. tekeanus

9(10) Pattern of marginal lobulation on collum: $2+2+2+2$.

(9) Pattern of marginal lobulation on collum different ... 13

11(12) Gap between frontalmost 1+1 lobulations considerably wider than incision between pairs on each side. Solenophore with a midway lobe .............. U. caudatus

12(11) Gaps/incisions between lobulations equally wide and deep. Solenophore unipartite

15

13(14) Length ca $9 \mathrm{~mm}$, width $1.7-1.8 \mathrm{~mm}\left(\mathrm{O}^{7}\right)$. Solenophore considerably longer than solenomere U. subaureus

14(13) Length ca $7 \mathrm{~mm}$, width $1.1 \mathrm{~mm}\left(\mathrm{O}^{7}\right)$. Solenomere nearly as long as solenophore ........................ U. aureus

15(16) Collum with $1+1+1$ extended, virtually undivided, marginal lobulations (Figs 16B \& 17A). Penultimate segment emarginate caudally (Fig. 16B \& 17C). Solenophore with a lobe in distal $1 / 3$ (Fig. 17D-F)

U. liber sp.n.

16(15) Collum with $5+3+3+5$ marginal lobulations (Fig. 14E).Penultimate segment subtruncate caudally (Fig.14C, G, J). Solenophore unipartite (Figs 14N \& 15)

U. harpago sp.n.

ACKNOWLEDGEMENTS. The first author is greatly obliged to the Musée Royal de l'Afrique Centrale, Tervuren, Belgium for the invitation to join this project. Special thanks go to Mrs Nadine Van Noppen and Dr. Arnaud Henrard (both MRAC) for executing some drawings or taking colour pictures, respectively. Part of this research was undertaken by Golder Associates and sub-consultants as a component of the Nimba Project ESIA for the Société des Mines de Fer de Guinée.

\section{References}

Attems C. 1953. Neue Myriopoden des Belgischen Congo // Annales du Musée Royal du Congo Belge, Tervuren. Série in $8^{\circ}$. Sciences Zoologiques. No.18. P.1-139 (for 1952).

Brolemann H.W. 1920. Myriapodes III, Diplopoda // Voyage de Ch. Alluaud et R. Jeannel en Afrique orientale (1911-1912). Résultats scientifiques. Paris, L. Lhomme. P.49-298.

Cook O.F. 1895. East African Diplopoda of the suborder Polydesmoidea, collected by Mr. William Astor Chanler // Proceedings of the United States National Museum. Vol.18. No.1042. P.81-111.

Cook O.F. 1896a. A new diplopod fauna in Liberia // The American Naturalist. Vol.30. P.413-420.

Cook O.F. 1896b. Summary of new Liberian Polydesmoidea // Proceedings of the Academy of Natural Sciences of Philadelphia. Vol.1896. P.257-266.

Demange J.-M., Mauriès J.-P. 1975. Myriapodes-Diplopodes des monts Nimba et Tonkoui (Côte d'Ivoire, Guinée) récoltés par M. Lamotte et ses collaborateurs de 1942 à 1960. Etude systématique, caractérisation des diopsiulides africains, révision des Trachystreptini, essai de classification des Cordyloporidae // Annales du Musée Royal de 1'Afrique Centrale, Tervuren. Série in $8^{\circ}$. Sciences Zoologiques. No.212. P.1-192.

Hoffman R.L. 1958. The systematic status of Stylodesmus, an endemic West African millipede genus (Polydesmida) // Revue de Zoologie et de Botanique Africaines. Vol.57. Nos 1-2. P.184-192.

Hoffman R.L. 1980. Classification of the Diplopoda. Genève: Muséum d'histoire naturelle. 237 p. (for 1979).

Jorgensen M.C., Sierwald P. 2010. Review of the Caribbean pyrgodesmid genus Docodesmus Cook with notes on potentially related genera (Diplopoda, Polydesmida, Pyrgodesmidae) // International Journal of Myriapodology. Vol.3. P.25-50.

Mauriès J.P., Maurin M. 1981. Pyrgodesmidae et Cryptodesmidae (Diplopoda, Polydesmida) de la forêt de Téke, Côte d'Ivoire // Bulletin du Muséum national d'Histoire naturelle, Sér.4. T.3. Section A. No.1. P.187-202.

Schubart O. 1955. Proterospermophora oder Polydesmoidea von Französisch West-Afrika (Diplopoda) // Bulletin de 1'Institut Français de 1'Afrique Noire, Sér.A. T.17. No.2. P.378-443.

Responsible editor K.G. Mikhailov 